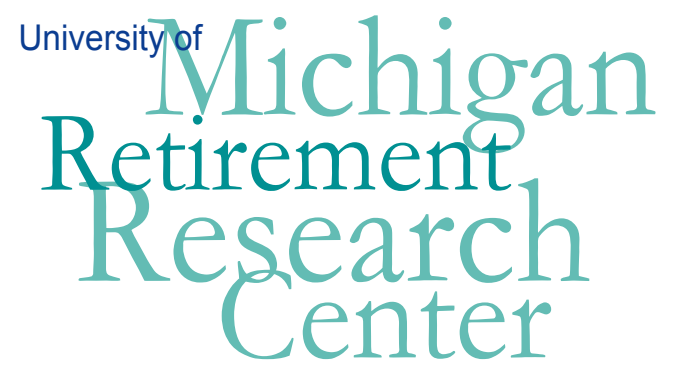

Working Paper

WP 2002-022

\title{
Dropping Out of Social Security
}

Kent Smetters and Jan Walliser

\begin{tabular}{|l|l|}
\hline $\mathrm{M}$ & $\mathrm{R}$ \\
\hline $\mathrm{R}$ & $\mathrm{C}$ \\
$\mathrm{y}$
\end{tabular}$\quad$ Project \#: UM01-01 


\title{
"Dropping Out of Social Security"
}

\author{
Kent Smetters \\ The Wharton School, University of Pennsylvania
}

\author{
Jan Walliser \\ The International Monetary Fund
}

January 2002

\author{
Michigan Retirement Research Center \\ University of Michigan \\ P.O. Box 1248 \\ Ann Arbor, MI 48104 \\ www.mrrc.isr.umich.edu \\ (734) 615-0422
}

\section{Acknowledgements}

This work was supported by a grant from the Social Security Administration through the Michigan Retirement Research Center (Grant \# 10-P-98358-5). The opinions and conclusions are solely those of the authors and should not be considered as representing the opinions or policy of the Social Security Administration or any other agency of the Federal Government.

\section{Regents of the University of Michigan}

David A. Brandon, Ann Arbor; Laurence B. Deitch, Bingham Farms; Daniel Horning, Grand Haven; Olivia P. Maynard, Goodrich; Rebecca McGowan, Ann Arbor; Andrea Fischer Newman, Ann Arbor; S. Martin Taylor, Gross Pointe Farms; Katherine E. White, Ann Arbor; Mary Sue Coleman, ex officio 


\title{
Dropping Out of Social Security
}

\author{
Kent Smetters and Jan Walliser
}

\begin{abstract}
The liability facing a pay-as-you-go social security system can be calculated in several ways. The exact liability measure chosen can significantly affect the conversion of a public pay-as-you-go system to a system based on individually funded accounts. Most conversions, including that which took place in Chile, as well as in many plans to convert the US system, assume the largest measure, known as the "shutdown liability." That measure pays many workers who have contributed to the public system more money than the public system is actually worth to them, thereby placing a larger burden on future generations. Other liability measures, though, are hard to implement due to an information asymmetry between the government and individuals about an individual's skill level.

This paper demonstrates that a very simple reform plan — simply letting people drop out of social security - generates a truthful revelation equilibrium in which agents reveal private information about their skill level. The new assumed liability measure can be as little as half of the shutdown liability as the new measure more accurately assigns a liability for each individual based on their true value of remaining in social security. A smaller liability, therefore, is passed to future generations which also generates quicker transition paths. Moreover, interestingly, the drop out method also does a better job of protecting the welfare of the initial elderly when general revenue is used to pay for the transition. Simulation evidence is provided using a large-scale lifecycle simulation model that allows for heterogeneous skill levels. The evidence demonstrates the importance of the dropping out approach relative to the traditional conversion method that assumes the shutdown liability.
\end{abstract}

\section{Authors' Acknowledgment}

The views expressed in the paper do not necessarily reflect the views of the International Monetary Fund. Helpful comments were received from seminar participants at The University of Virginia, Oxford University and The Wharton School. Very helpful comments were received from Laurence Kotlikoff and Olivia Mitchell. Kent Smetters participation was sponsored by a grant from the Social Security Administration (MRRC-UM01-01). 


\section{Introduction}

Chile, when it converted its pay-as-you-go social insurance system to individual definedcontribution accounts, recognized previous contributions by workers made under the public insurance system by crediting contributions with a four percent real annual interest rate. People who were retired at the time of the reform continued to collect benefits under the old system. Credits were distributed to workers in the form of "recognition bonds" that were placed in each worker's new individual account. Bonds are paid off by using general revenue when the worker retires.

Many analyses of converting the U.S. Social Security system to individual funded accounts also phase out Social Security benefits based on former contributions. See Feldstein (1975), Seidman (1983), Arrau and Schmidt-Hebbel (1993), Feldstein (1995), Kotlikoff (1996), Kotlikoff, Smetters and Walliser (1997), Altig and Gokhale (1997), Feldstein and Samwick (1997), and Huang, İmrohoroğlu, and Sargent (1997). Participation in the new system is generally mandatory in these plans, presumably to avoid adverse selection. Gustman and Steinmeier (1995) consider partialequilibrium responses to allowing people to choose between private saving and social security.

To be sure, the focus on previous contributions is understandable since that measure can be easily calculated. But it is also easy to see why that measure overpays many participants: for many younger and richer agents, remaining in social security is actually a bad deal. If the market rate of return that agents could receive on private investments exceeds the internal rate of return to social security, the present value of their future social security benefits is smaller than the present value of their future social security taxes. Paying these agents money to recognize their previous contributions, therefore, gives them more than social security is actually worth to them. These agents would be willing to pay to get out of social security.

A more accurate measure of social security's worth to each person would be based on prospective contributions and benefits, not past contributions. However, it is hard for the government 
to calculate a prospective value of social security for each person. As in the optimal tax literature started by Mirrlees (1971), suppose that each agent knows his or her own lifetime skill level which is drawn from a distribution of lifetime skill levels. The government, however, only observes each agent's endogenous wage income but not hours worked. Each agent's lifetime skill level, therefore, is private information. ${ }^{1}$ To project future labor earnings, however, the government must know an agent's skill level since two agents with nearly identical labor income histories can belong to very different lifetime skill income classes. An agent with a high eventual lifetime income could have low earnings during early his or her working years due to heterogeneity in the curvature of lifecycle skill profiles caused by education, heterogenous bequests and a progressive social security system. Future earnings projections would especially difficult for the government to make for younger workers with a limited work history. Not surprising, therefore, previous plans to convert social security to individual accounts make no effort to calculate prospective taxes and benefits.

This paper demonstrates that a simple reform plan — simply letting people drop out of social security — does a better job at identifying the winners and losers under social security relative to the common liability measure based on previous contributions. An agent who drops out no longer faces future payroll taxes but also forfeits any accrued benefits: they simply drop out. An agent will drop out if the present value of their remaining social security taxes exceeds benefits. Dropping out is not perfect: agents with a negative present value do not have to pay their way out of social security. ${ }^{2}$ However, social security's liability stemming from those who remain in social security is potentially much less than the liability based on previous contributions (see below). Future workers, therefore, face a smaller burden since many current workers are no longer being overpaid. The transition to the

\footnotetext{
${ }^{1}$ Our approach is the same as in the optimal tax literature: an agent's skill level is fully certain to them but unknown to the government. But we allow for more than one period, and so we consider an agent's lifetime skill level.

${ }^{2}$ Attempting to force agents to pay their way out would cause them to mis-state their projected net present value as zero since that is private information. See the discussion below.
} 
new steady state, therefore, is also quicker. Moreover, interestingly, if general revenue is being used to finance the transition, as in Chile and many other plans, the dropping out approach can even be more successful in protecting the welfare of the initial elderly.

Section II presents the mathematics of the basic social security liability measures inside of a three-period OLG model. That section shows how, relative to the traditional conversion method based on previous contributions, allowing for dropping out better matches how much a transitional worker is paid under conversion relative to how much social security is actually worth to them. Section III outlines a large-scale simulation model that is used to demonstrate the importance of the dropping out approach versus the traditional approach that compensates workers based on previous contributions. The model allows for heterogeneous skill levels. Section IV reports the distributional and macroeconomic results of the traditional method. Section V reports the results for the dropping out approach and draws some comparisons. Section VI concludes.

\section{The Mathematics of Social Security Liability Measures}

Consider a lifecycle model where agents work for two periods and retire in the third. $c_{j, t}$ and $a_{j, t}$ equal the consumption and asset holdings, respectively, of a $j$-year old at time $t . w_{j, t}$ is the wage

rate for a person who is age $j$ at time $t$. Wages grow at a constant rate $g: g=w_{j, t+1} / w_{j, t}-1 . r$ is the constant return to capital. The proportional social tax rate is given by $\tau$. The agent who is age 1 at time $t$ faces the following sequence of budget constraints throughout his/her lifetime in steady state:

$$
\begin{gathered}
c_{1, t}+a_{1, t}=(1-\tau) w_{1, t} \\
c_{2, t+1}+a_{2, t+1}=(1-\tau) w_{2, t+1}+(1+r) a_{1, t} \\
c_{3, t+2}=(1+r) a_{2, t+1}+b_{t+2}
\end{gathered}
$$

The pay-as-you-go social security benefit paid at time $t+2$ equals taxes collected at time $t+2$ :

$$
b_{t+2}=\tau \cdot w_{1, t+2}+\tau \cdot w_{2, t+2}
$$


A social security system's liability can be calculated several ways. The "shutdown liability" equals the amount that social security owes existing workers and retirees based on previous contributions. ${ }^{3}$ The expression "shutdown liability" reflects the fact that the measure assumes no future payroll tax revenue. Previous contributions are credited at the internal rate of return to social security, $g .{ }^{4}$ Let $B_{t}^{S D}$ denote the benefit owed to generation $t$ under the shutdown measure. For the three generations - indexed as $t-2$ (grandparents), $t-1$ (parents) and $t$ (children) - alive at time $t$ :

$$
\begin{gathered}
B_{t-2}^{S D}=\tau \cdot w_{1, t-2} \cdot(1+g)^{2}+\tau \cdot w_{2, t-1} \cdot(1+g)=b_{t} \\
B_{t-1}^{S D}=w_{1, t-1} \cdot \tau \cdot(1+g)=w_{1, t} \cdot \tau \\
B_{t}^{S D}=0
\end{gathered}
$$

Social security owes generation $t-2$ the entire social security benefit, $b_{t}$, because that generation is already retired at time $t$, and so crediting their previous benefits at social security's internal rate of return gives them $b_{t}$. The amount owed to generation $t-1$ only equals their contribution made during their first period of life appreciated at the rate $g$ since the shutdown liability is assumed to be measured at the beginning of time $t$ before any second-period contribution is made. For the same reason, generation $t$ is not owed anything because they have not contributed in the past.

Another liability measure is the "on-going liability." Under this measure, the amount that social security owes each generation equals the present value of future benefits less future taxes. Past contributions are "sunk." This measure, therefore, captures an agent's opportunity cost of remaining in social security. The expression "on-going liability" reflects the fact that future payroll tax revenue is taken into consideration when calculating the liability measure. Let $B_{t}^{O G}$ denote the benefit owed to generation $t$ under the "on-going" liability measure. Then:

\footnotetext{
${ }^{3}$ The shutdown measure has also been called the "maximum transition cost" (Goss, 1999) and the "backward looking” recognition of liabilities (Feldstein and Samwick, 1997). See also Geanakoplis, Mitchell, and Zeldes (1999).

${ }^{4}$ This assumption is conservative as many conversions plans would credit past contributions at a market rate.
} 


$$
\begin{gathered}
B_{t-2}^{O G}=b_{t} \\
B_{t-1}^{O G}=\frac{b_{t+1}}{(1+r)}-\tau \cdot w_{2, t}=\frac{\tau \cdot w_{1, t} \cdot(1+g)}{(1+r)}+\tau \cdot w_{2, t} \cdot\left(\frac{1+g}{1+r}-1\right) \\
B_{t}^{O G}=\frac{b_{t+1}}{(1+r)^{2}}-\left(\tau \cdot w_{1, t}+\frac{\tau \cdot w_{2, t+1}}{1+r}\right)=\tau \cdot w_{1, t} \cdot\left[\frac{(1+g)^{2}}{(1+r)^{2}}-1\right]+\frac{\tau \cdot w_{2, t+1}}{1+r} \cdot\left(\frac{1+g}{1+r}-1\right)
\end{gathered}
$$

If the market interest rate exceeds the economy's rate of growth $(r>g)$ as in an efficient economy, then the benefit owed to the youngest worker, $B_{t}^{O G}$, is negative. The benefit owed to the middleaged worker, $B_{t-1}^{O G}$, might also be negative if their skill level, measured by $w_{2, t}$, is large enough.

The "on-going-with-floor liability" is the same as the "on-going liability" except that any negative values of $B^{O G}$ are converted to zero (the floor). Let $B_{t}^{O G-F}$ denote the value of the benefit owed to generation $t$ under the "on-going-with-floor" liability. Then, for $r>g$, we have:

$$
\begin{gathered}
B_{t-2}^{O G-F}=\max \left[B_{t-2}^{O G}, 0\right]=B_{t-2}^{O G}=b_{t} \\
B_{t-1}^{O G-F}=\max \left[B_{t-1}^{O G}, 0\right] \\
B_{t}^{O G-F}=\max \left[B_{t}^{O G}, 0\right]=0
\end{gathered}
$$

Proposition 1. If $r>g$, then $\sum_{s \in \mathrm{T}} B_{s}^{O G}<\sum_{s \in \mathrm{T}} B_{s}^{O G-F}<\sum_{s \in \mathrm{T}} B_{s}^{S D}, s \in \mathrm{T}=\{t-2, t-1, t\}$.

Proposition 1 states that, in a dynamically efficient economy, the total on-going liability of a mature pay-as-you-go social security system in steady state is less than on-going-with-floor liability which is less than the shutdown liability. The proof follows from recognizing that, when $r>g$,

$$
B_{s}^{O G} \leq B_{s}^{O G-F} \leq B_{s}^{S D}
$$

for all $s \in \mathrm{T}=\{t-2, t-1, t\}$, with each inequality holding strictly for at least one value of $s$. 
Proposition 2. If agents can drop out of social security, thereby forfeiting all future benefits, then the net present value of social security benefits to be paid in the future equals $\sum_{s \in \mathrm{T}} B_{s}^{O G-F}$ if $r>g$.

To prove Proposition 2, note that the young generation- $t$ agent will drop out of social security since $B_{t}^{O G}<0$ when $r>g$, i.e., their present value of future payroll taxes exceeds benefits. The middle-age generation-( $t-1)$ will drop out if $B_{t-1}^{O G}$ is negative. The condition $r>g$ guarantees that no future generation will choose social security. The total amount that social security must pay existing workers after allowing for dropping out at time $t$, therefore, equals $\sum_{s \in \mathrm{T}} B_{s}^{O G-F}$.

It follows from Propositions 1 and 2 that the net present value of future social security payments is smaller under the dropping out approach relative to the more common conversion method which pays off the system's shutdown liability. The inequalities shown in Proposition 1, and the on-going-with-floor liability associated with the dropping out approach, holds even if more heterogeneity is introduced in the model, including along skill levels (as below). ${ }^{5}$ For the US Social Security system, Feldstein and Samwick (1997) estimate that the total shutdown liability, $\sum_{s \in \mathrm{T}} B_{s}^{S D}$, equals $\$ 11.3$ trillion at a four percent interest rate while the total on-going-with-floor liability, $\sum_{s \in \mathrm{T}} B_{s}^{O G-F}$, equals about $\$ 7$ trillion, or almost half. These values imply that, relative to the dropping out approach, traditional plans to convert the US system to individual accounts would pay current workers almost double the amount that Social Security is actually worth to them.

To be sure, an even better matching of liabilities could be achieved if the government computed the on-going liability, $B^{O G}$, for each individual and forced agents with negative values to pay their way out. However, in a more realistic world with heterogenous skills considered below,

${ }^{5} B_{t}^{O G-F}=\max \left[B_{t}^{O G}, 0\right]$ may no longer equal zero for all agents with heterogeneity. But the inequalities shown in Proposition 1, and the equality between the liability associated with the dropping out plan and the on-going-with-floor liability measure (Proposition 2), still holds. 
that calculation requires more information than is available to the government since each agent's lifetime income skill level is private information. As a result, attempting to force agents to pay their way out of social security would not generate a truthful revelation equilibrium: agents facing a negative net present value of remaining in social security would have an incentive to state their value as close to zero. But simply allowing for dropping out is quite powerful. Agents who drop out reveal important information about their skill level - namely, their skill is high enough that they face a negative net present value for remaining in social security. Relative to the standard conversion method toward individual accounts that assumes the shutdown liability, the dropping out approach better matches benefits owed to existing workers relative to social security's true worth to them.

\section{The Simulation Model}

This section uses a new perfect foresight dynamic simulation model to compare the equity and macroeconomic effects of privatizing social security. The model is a substantially enhanced version of the Auerbach-Kotlikoff(1987) life-cycle overlapping-generations model. The new model incorporates (i) heterogeneous skill levels based on micro-data estimation; (ii) the salient features of the US social security system as well as a simple treatment of the Medicare and Disability Insurance programs, and (iii) a detailed description of the US federal and state tax system. Although the model is calibrated to the US economy, its findings present general lessons.

\section{$\underline{\text { Demographic Structure }}$}

The model's cohorts are distinguished by their dates of birth and their lifetime laborproductivity skills. Following Fullerton and Rogers (1993), each birth cohort includes 12 lifetime 
skill groups. ${ }^{6}$ Each of these 12 groups has its own initial endowment of human capital and its own pattern of growth in this endowment over its lifetime. The lifetime-earnings groups also differ with respect to their bequest preferences. All agents live for 55 periods with certainty (corresponding to adult ages 21 through 75), and each $j$-type generation is $1+n$ times larger than its predecessor. Population growth is exogenous, and each cohort is $(1+n)^{20}$ larger than its parent cohort.

\section{Preferences and Household Budget Constraints}

Each $j$-type agent who begins her economic life at date $t$ chooses perfect-foresight consumption paths $(c)$, leisure paths $(l)$, and intergenerational transfers $(b)$ to maximize a time-separable utility function of the form

$$
U_{t}^{j}=\frac{1}{1-\frac{1}{\gamma}}\left[\sum_{s=21}^{75} \beta^{s-21}\left(c_{s, t+s-21}^{j}+\alpha l_{s, t+s-21}^{j-\frac{1}{\rho}}\right)^{1-\frac{1}{\rho}}+\beta^{\frac{1-\frac{1}{\gamma}}{1-\frac{1}{\rho}}} \mu^{j} b_{75, t+54}^{j}\right] .
$$

In (1) $\alpha$ is the utility weight on leisure, $\gamma$ is the intertemporal elasticity of substitution in the leisure/consumption composite, and $\rho$ is the intratemporal elasticity of substitution between consumption and leisure. The parameter $\mu^{j}$ is a $j$-type specific utility weight placed on bequests left to each child when the agent dies. The term $\beta=1 /(1+\delta)$ where $\delta$ is the rate of time preference.

Letting $a_{s, t}^{j}$ be capital holdings for type $j$ agents, of age $s$, at time $t$, maximization of (1) is subject to a sequence of budget constraints given by

$$
a_{s+1, t+1}^{j}=\left(1+r_{t}\right)\left(a_{s, t}^{j}+g_{s, t}^{j}\right)+w_{s, t}^{j}\left(E_{s, t}^{j}-l_{s, t}^{j}\right)-c_{s, t}^{j}-\sum_{k \in \tilde{\mathrm{T}}} T^{k}\left(B_{s, t}^{j, k}\right)-N b_{s, t^{*}}^{j}
$$

${ }^{6}$ Our model has several strengths relative to Fullerton and Rogers (1993) and, at least, one weakness. The strengths include a rational-expectations solution, a social security system, a tax system with progressive marginal tax rates, an array of tax base reductions, government debt, bequests, and other features. However, the model lacks the multi-sectoral detail on the production side present in the Fullerton-Rogers model. The omission of this production detail probably has little relevance for our purposes since privatization does not change the inter-sectoral distortions. 


$$
l_{s, t}^{j} \leq E_{s, t}^{j}
$$

where $r_{t}$ is the pretax return to savings, $g_{s, t}^{j}$ are gifts received from parents, $E_{s, t}{ }^{j}$ is the time endowment, $b_{s, t}^{j}$ denotes bequests made to each of the $N=(1+n)^{20}$ children, and the functions $T^{k}(\cdot)$ with tax base arguments $B_{s, t}^{j, k}$ determine net tax payments from income sources $k \in \tilde{\mathrm{T}}=\{C, K, W$, $Y, P\} . T^{C}(\cdot), T^{K}(\cdot), T^{W}(\cdot), T^{Y}(\cdot)$ and $T^{P}(\cdot)$ are consumption taxes, capital income taxes, wage taxes, income taxes and social security payroll taxes, respectively. Social security benefits are represented in equation (2) as negative taxes with the base switching at the point of retirement from the contemporaneous payroll base to average indexed yearly earnings in the pre-retirement years. All taxes are collected at the household level and the tax system includes both a personal income tax and a business profits tax. The construction of the functions $T^{k}(\cdot)$ is described in detail in the Appendix.

An individual's earnings ability is a function of age, skill, and the level of labor-augmenting technical progress which grows at a constant rate $\lambda$. We concentrate all skill differences in an efficiency parameter $\epsilon_{s}^{j}$. Thus, the wage rate for an agent of type $j$ and age $s$ is $w_{s, t}^{j}=\epsilon_{s}^{j} w_{t}$, where $w_{t}$ is the growth-adjusted real wage at time $t . \epsilon_{s}^{j}$ increases with age to reflect not only the accumulation of human capital, but also technical progress. To permit balanced growth for our flexible specification for preferences, given the restriction on leisure shown in equation (2), the time endowment of each successive generation also grows at rate $\lambda .^{7}$ Thus, if $E_{s, t}{ }^{j}$ is the endowment of type $j$ at age $s$ and time $t$, then $E_{s, t}{ }^{j}=(1+\lambda) E_{s, t-1}{ }^{j}$, for all $s, t$, and $j$. Notice that $E_{s, t}{ }^{j}$ depends only on an agent's year of birth. Since $E$ grows at rate $\lambda$ from one cohort to the next, there is no trend in $w_{t}$. The growth-adjusted earnings ability profiles take the form

\footnotetext{
${ }^{7}$ See Auerbach, et al. (1989) for a more complete discussion of this strategy for dealing with balanced growth.
} 


$$
\epsilon_{s}^{j}=e^{a_{0}^{j}+a_{1}^{j} s+a_{2}^{j} s^{2}+a_{3}^{j} s^{3}} .
$$

Values of the $a$ coefficients for $j$-type groups 1 through 12-in ascending order of lifetime income - are based on regressions fitted to the University of Michigan's Panel Study of Income Dynamics and are taken from Altig, Auerbach, Kotlikoff, Smetters and Walliser (1997). Groups 1 and 12 comprise the bottom and top 2 percent of lifetime wage income earners, and groups 2 and 11 the remaining 8 percent of the top and bottom deciles. All other groups constitute 10 percent of the population. For example, group 3 is the second decile of lifetime-wage income, group four the third decile, and so on up to group 10 . The estimated earnings-ability profiles, scaled to include the effects of technical progress. Given our benchmark parameterization, peak hourly wages valued in 1996 dollars are $\$ 4.00, \$ 14.70$, and $\$ 79.50$ for individuals in classes 1,6 , and 12 , respectively. More generally, steady-state annual labor incomes derived from the model's assumptions and the endogenous labor supply choices range from $\$ 9,000$ to $\$ 130,000$. These calculations do not yet include labor compensation in the form of fringe benefits (discussed below).

Transfers are received by children, with interest, at the beginning of the period after they are made by their parents. We restrict all parental transfers to bequests, so that $b_{s, t}^{j}=0$, for $s \neq 75$, and $g_{s, t}^{j}=0$, for $s \neq 56$. In the steady state, therefore, $g^{j}=b^{j}$, for all $j$ (where we have dropped the age subscripts for convenience). The parameters $\mu^{j}$ are derived endogenously for the initial steady state such that the ratio of the bequest to economy-wide mean income corresponds to the ratio originally estimated by Menchik and David (1982) and updated by Fullerton and Rogers (1993). Bequests range from $\$ 4,800$ to $\$ 450,000$ for the lowest and highest lifetime earnings classes, respectively.

Choices for the remaining technology, preference, and demographic parameters are summarized in Table 1. The benchmark values for $\delta, \gamma, \rho$, and $n$ follow Auerbach and Kotlikoff (1987). $\alpha$ is chosen so that agents devote, on average, 40 percent of their available time endowment 
(of 16 hours per day) to labor during their prime working years (real-life ages of roughly 21-55).

\section{The Non-Social Security Government Budget Constraint}

At each time $t$, the government collects tax revenues and issues debt $\left(D_{t+1}\right)$ which it uses to finance government purchases of goods and services $\left(G_{t}\right)$ and interest payments on the inherited stock

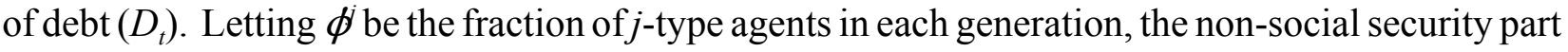
of the government's budget constraint evolves according to

$$
D_{t+1}+(1+n)^{t} \sum_{j=1}^{12} \phi^{j} \sum_{s=21}^{75}(1+n)^{-(s-21)} \sum_{k \in\{\tilde{T}-P\}} T^{k}\left(B_{s, t}^{j, k}\right)=G_{t}+\left(1+r_{t}\right) D_{t}
$$

Social security taxes are earmarked to pay benefits and so do not appear in equation (4).

Government expenditures are assumed to generate no utility to households. ${ }^{8}$ The values of $G_{t}$ and $D_{t}$ are held fixed per effective worker throughout the transition path. Any reduction in government outlays resulting from a change in the government's real interest payments is passed on to households in the form of a lower tax rate. The level of government debt, $D_{t}$, was chosen such that the associated real interest payments equal about 3.5 percent of national income in the initial steady state. The statutory tax schedules (described in the Appendix) generate a level of revenue above debt service such that the benchmark steady-state ratio of government purchases, $G_{t}$, to national income equals 0.239 . These values correspond closely to the corresponding 1996 values for the combined local, state, and federal government in the United States. See Table 2.

$\underline{\text { Social Security, Medicare and Disability }}$

The model has a social insurance system that incorporates social security Old-Age and Survivors Insurance (OASI), Social Security Disability Insurance (DI), and Medicare (HI).

\footnotetext{
${ }^{8}$ Since $G$ remains fixed in all of our experiments, incorporating $G$ into the utility function is unimportant.
} 
OASI benefits are calculated according to the progressive statutory bend-point formula. U.S. Social Security benefits are based on a measure of average indexed monthly earnings (AIME) over a 35-year work history. The AIME is converted into a primary insurance amount (PIA) in accordance with a progressive formula. In particular, the 1996 benefit formula has two bend points. The PIA is calculated as 90 percent of the first $\$ 437$ of AIME, 32 percent of the next \$2,198 of AIME, and 15 percent of AIME above $\$ 2,198$. We achieve replacement values between 25 and 75 percent for the lifetime richest and lifetime poorest, respectively. Since approximately 50 percent of Social Security benefits are paid to survivors and spouses, we multiply benefits by a factor of two.

An earmarked tax applied to wage income up to a limit of $\$ 62,700$ - the earnings ceiling in 1996 - is used to pay for OASI benefits. Define $\omega_{s, t}^{j} \equiv w_{s, t}^{j}\left(E_{s, t}^{j}-l_{s, t}^{j}\right)$ as the wage income earned by the $j$-type agent who is age $s$ in year $t$. Also define $\bar{\omega}_{65, t}^{j}$ as the average indexed annual earnings for the $j$-type agent age 65 at time $t$. Labor income earned before turning age 65 is adjusted upward by the growth rate of the economy in calculating $\bar{\omega}_{65, t}^{j}$. Payroll taxes at time $t$-with retirement benefits modeled as negative taxes - equals

$$
T^{P}\left(B_{s, t}^{j, k}\right)=\left\{\begin{array}{ll}
\tau \cdot \omega_{s, t}^{j} & ; s \leq 64, \omega_{s, t}^{j} \leq \$ 62,700 \\
\tau \cdot \$ 62,700 & ; s \leq 64, \omega_{s, t}^{j}>\$ 62,700 \\
-2 \cdot R\left(\bar{\omega}_{s, t}^{j}\right) \cdot \bar{\omega}_{s, t}^{j} & ; s>64
\end{array}\right\}
$$

where $R(\cdot)$ is the statutory replacement rate function shown in Figure 1.

A self-financing pay-as-you-go social security system with earmarked taxes implies,

$$
\sum_{j=1}^{12} \phi^{j} \sum_{s=21}^{75}(1+n)^{-(s-21)} T^{P}\left(B_{s, t}^{j, P}\right)=0
$$


The value of $\tau$ is solved for endogenously as a function of benefit rules via equation (6). The value of $\tau$ is 9.9 percent in the initial steady state, which is close to its actual value in $1996 .{ }^{9}$

What matters for economic decision making is not the statutory payroll tax rate but the net marginal payroll tax rate which is equal to the tax paid on an extra dollar of wage income less the present value of additional benefits received. Let $P V T\left(\omega_{s, t}^{j}\right)$ and $P V B\left(\omega_{s, t}^{j}\right)$ be the present value of payroll taxes and benefits, respectively, for the $j$-type agent age $s$ at time $t$. The net marginal tax rate for agents whose income falls below the earnings ceiling is,

$$
\theta\left(\omega_{s, t}^{j}\right)=\tau \cdot\left[1-P V B^{\prime}\left(\omega_{s, t}^{j}\right) / P V T^{\prime}\left(\omega_{s, t}^{j}\right)\right]
$$

where $P V B^{\prime}(\cdot)=\partial P V B(\cdot) / \partial \omega$ and $P V T^{\prime}(\cdot)=\partial P V T(\cdot) / \partial \omega$. Net marginal tax rates for the initial steady state are shown in Figure 2 by income class and age. These tax rates are typically relatively higher for both richer and younger agents. The higher rates for richer agents reflect progressive social security benefits. The higher rates for younger agents reflect the compound interest effect of being required to save in a social security system whose internal rate of return is less than after-tax rate of return to capital (reported below). Notice that the net tax rates are generally quite large and positive even for the lifetime poor because the after-tax rate of return to capital is higher than the internal rates of return faced by even these agents. Rich agents whose labor income exceeds the payroll tax (e.g., class 12 in select years) face a zero marginal tax rate.

The HI and DI programs are modeled very simply. The HI and DI levels of lump-sum transfers are picked to generate payroll tax rates of 2.9 percent and 1.9 percent, respectively, corresponding to their 1996 statutory rates. Like the OASI tax, DI contributions apply only to wages below $\$ 62,700$. The HI tax, in contrast, is not subject to an earnings ceiling. Lump-sum HI and DI

\footnotetext{
${ }^{9}$ The employer-employee combined payroll tax equaled 10.52 percentage points. About 1 percentage point represents a net increase to the social security trust fund which we take as basically neutral herein.
} 
benefits are provided on an equal basis to agents above and below age 65 , respectively.

\section{Aggregation and Technology}

Aggregate capital $(K)$ and labor $(L)$ are obtained from individual asset and labor supplies as

$$
K_{t}=(1+n)^{t} \sum_{j=1}^{12} \phi^{j} \sum_{s=21}^{75}(1+n)^{-(s-21)} a_{s, t}^{j}-D_{t}
$$

(where, recall, $D_{t}$ is government debt at time $t$ ) and

$$
L_{t}=(1+n)^{t} \sum_{j=1}^{12} \phi^{j} \sum_{s=21}^{75}(1+n)^{-(s-21)} \epsilon_{s}^{j}\left(E_{s, t}^{j}-l_{s, t}^{j}\right) .
$$

Output (net of depreciation) is produced by identical competitive firms using a neoclassical, Cobb-Douglas production technology:

$$
Y_{t}=A K_{t}^{\theta} L_{t}^{1-\theta}
$$

where $Y_{t}$ is aggregate output (national income) and $\theta$ is capital's share in production. Denote the capital-labor ratio as $\kappa$. The time- $t$ competitive post-tax capital rate of return equals

$$
r_{t}=\left[\theta A \kappa_{t}^{\theta-1}\left(1-\tau_{t}^{K}\right)+q_{t+1}-q_{t}\right] / q_{t}
$$

where $q_{t}=\left(1-z_{t} \tau_{t}^{K}\right)$ is Tobin's q at time $t$ and $z$ is the level of capital investment expensing.

Given our parameter choices, the model generates a pre-tax interest rate of 9.3 percent, a net national saving rate of 5.3 percent, and a capital/national-income ratio of 2.6. Consumption accounts for 73.4 percent of national income, net investment for 5.2 percent, and government purchases of goods and services for 21.4 percent. These figures are close to their respective 1996 NIPA values. The post-tax interest rate equals 0.08 and is calculated following Auerbach (1996). Summary 
statistics for the initial economy are provided in Table 2.

\section{$\underline{\text { Limitations }}$}

The model herein incorporates many complex features of the economy and fiscal institutions. However, as any model, our model also abstracts in important ways from reality and the exact numerical results should therefore be interpreted cautiously. While the model captures the fact that Social Security provides retirement income and redistributes from rich to poor, it does not incorporate aggregate rate of return risk. The paper therefore does not deal with the unfunded liability facing government as the insurer of last resort. Relaxing these assumptions could lead to both smaller shortrun costs along with smaller long-run gains. The paper also assumes that adverse selection in the private annuities market is effectively dealt with via mandated annuitization.

Certain aspects of the model understate the long-run utility gains, including modeling the general-equilibrium decline in the interest rate associated with privatization in a closed economy.

Other model assumptions have a less clear impact. For example, while introducing binding borrowing constraints reduces the degree that Social Security reduces private saving, including them would also make Social Security's high payroll tax even more utility decreasing. Privatization, therefore, would tend to lead to larger utility gains with borrowing constraints than without them.

Nonetheless, the main focus of this paper is on the relative comparison of forced participation plans versus dropping out. The ability of dropping out to better protect the utility of the initial elderly and to provide for quicker convergence is likely to be robust to numerous assumptions.

\section{Traditional Conversion: The Shutdown Liability}

The tradition conversion to private accounts involves three steps: a) give retirees and workers social security benefits equal to the amount accrued at the time of the reform based on previous contributions; b) finance social security benefits during the transition period; and c) require workers 
to contribute to new private accounts.

Regarding step a), social security benefits are phased out starting 10 years after the privatization reform occurs in order to give current retirees the same benefits they would otherwise have received. In the model, social security benefits are received for 10 years from 45 to 55 (real age 65 to real age 75$)$. Starting in the 11 th year of the reform, we phase out social security benefits by 2.2 percent (of the baseline benefits) per year for 45 years. This approach closely approximates giving existing workers a level of benefits proportional to their previous contributions, consistent with the shutdown liability measured outlined in Section II. ${ }^{10}$

Regarding step b), we consider two alternative tax bases to pay for social security benefits during the transition: the income tax base with the tax base reductions outlined in the Appendix and a consumption tax base. The simulations using the income tax base might be the most relevant for the US, although a consumption base could also be used. Some European nations might use the consumption base. In both cases, the taxes are temporary and go to zero after the transition.

Privatization alters the long-run capital stock, national income and, hence, the income-tax base. Since we maintain a constant level of government purchases per effective worker in each transition, we need to adjust income-tax rates along the transition path even in those simulations in which income taxes are not used to pay the social security benefits accrued under the old system. The shares of (endogenous) revenues to be made up by the two components of the income tax, the progressive wage tax and the proportional capital income tax, are determined such that the average wage tax and the average capital income change proportionally.

Regarding step c), in our model, privatizing social security contributions just requires setting

\footnotetext{
${ }^{10}$ As discussed in Geanakoplis, Mitchell, and Zeldes (1999), this approach is conservative. If, instead, we computed each worker's benefit by simply filling in zeros into the Social Security benefit formula for the rest of their lifetime earnings, then workers would receive an even larger benefit due to the progressivity of the benefit formula. We assume that each worker has enough work experience to qualify for benefits, or would be treated as so under conversion.
} 
the model's social security payroll tax rate to zero; i.e., there is no need to add a formal private pension system to the model. Since the agents in our model are not liquidity constrained, forcing them to contribute to private accounts will not affect their net saving or labor supply decisions because they are free to borrow against their mandated retirement accounts. That said, it is worth noting that in the particular economies simulated herein, only the poorest 10 percent of agents actually seek to borrow against social security. So if we added a liquidity constraint to the model (specifically, a constraint against negative net wealth), it would not materially alter our findings.

\section{$\underline{\text { Macroeconomic Effects }}$}

Tables 3 - 7 present the macroeconomic effects of six alternative privatization reforms. Runs 1 and 2 correspond to traditional privatization method explored; the remaining runs correspond to dropping out explored in the next section. The top panels of Figures 3 and 4 graph the information corresponding to runs 1 and 2. Year 1 (1997) is the first year of the transition path and so, for example, an agent born (economically) in year -10 is 11 years old (age 31 in real-life).

Consider first Runs 1 and 2 which use the income tax base and consumption tax base, respectively, to pay off remaining benefits (the shutdown liability) during the transition to a new privatized system. Both runs produces the same long-run results. The capital stock rises by 39 percent, labor supply rises by 5 percent, output per person rises by 13 percent, the real wage rises by 7 percent, and the real interest rate falls by 19 percent. The speed of adjustment, however, depends critically on the choice of the tax based used to pay off existing benefits. In the case of income-tax finance, the capital stock is actually 5 percent smaller 25 years after the transition, notwithstanding the fact that it ultimately ends up 39 percent larger. With consumption-tax finance the transition is much faster, but it's still rather slow. After 25 years the capital stock is 13 percent larger which is only one-third of its long-run increase. Slow transitions are a common feature of neoclassical 
models; however, these transitions are especially slow.

The slow transition is explained in a large part by the large shutdown liability that is being paid off under the traditional method of conversion. Social security benefits are reduced gradually over a 55-year period and even agents whose net present value of remaining in Social Security is negative receive something in return for their previous contributions. This overpayment of benefits is a non-trivial drain on the transitional economy. The transition is especially slow in the income-tax finance case where marginal tax rates on labor supply and capital income are quite high in the short run. The high tax rates encourage households to substitute current leisure and consumption for future leisure and consumption. Indeed, in the case of income-tax finance, the short-term disincentive to work leads to a 5 percent decline in aggregate labor supply.

With consumption tax financing, the short-run saving incentives are quite different. The additional consumption tax starts out at a 10 percent rate and then declines over time to zero. The temporarily high price of consumption gives agents an incentive to delay their consumption expenditures and, consequently, save more. Moreover, using the consumption tax rather than an income to finance transitional social security benefits places a larger fiscal burden on the initial elderly and a lower one on those who are young and middle aged, through an efficient one-time tax on existing non-social security wealth. Since the elderly, who are closer to the end of their lives, have higher propensities to consume than do the young and middle aged, redistributing from them to younger cohort leads to less overall consumption and more national saving.

\section{$\underline{\text { Welfare Effects }}$}

Table 8 and the bottom panels of Figures 3 and 4 show the welfare effects of the different Social Security reforms. The welfare effects are measured as the percentage increase in both consumption and leisure in each year of remaining life (entire life for newborns) in the pre-privatized 
economy needed to generate the same level of utility the agent enjoys as a result of the privatization reform (i.e., the equivalent variation). Notice that the long-run welfare gain exceeds 4 percent for each income class, and are larger for middle income classes. Class 9, for example, enjoys an 8 percent gain. The gain for the top income class 12 is 4 percent, and 6 percent income class 1 .

What explains these differences? The answer is that different features of the privatization policy affect income groups differently. First, we are eliminating the progressive social security benefit schedule. Second, we are eliminating the social security payroll tax which is regressive due to the ceiling on taxable earnings. Third, we are adjusting downward long-run income tax rates as the income tax base increases with the long-run improvement of the economy. This reduction in income-tax rates helps income-tax payers, a set of agents that does not include the very poor who pay no income taxes because of the tax exemptions and deductions. Fourth, eliminating social security's payroll tax has a bigger impact on households with higher earnings since they already face a higher marginal income tax rate. Since the distortion rises approximately with the square of the tax rate, those households face a multiple of the labor supply distortion of low income households. However, households with earnings above the payroll tax ceiling in the initial steady state (class 12) benefit less from privatization since their labor supply is not affected by the payroll tax at the margin.

The tables and figures show not only the long-run winners from privatization, but also the short-run losers. Financing the transition with an income tax (Run 1) puts a higher burden on the middle class and especially the very high income classes. This result follows from the specifics of the income tax code which exempts low income households from taxation. Class 1 does not contribute at all to financing the transition when income-tax finance is employed. Class 12 , however, gets hit especially hard since the non-distorting payroll tax (class 12's income exceeds the payroll tax ceiling) is replaced by a fully distorting income tax. Income tax financing of the transition also raises the tax rate on capital income which affects high earners the most. 
Finally, consider consumption-tax financing (Run 2). Nearly all generations over age 25 (real age 45) at the time of the reform are made worse off by the reform, although their welfare losses are moderate. (The exception is the 54-year olds in income class 1 who are paying back a loan against social security benefits; recall that only income class 1 borrows.) In the case of initial 54 year-olds, shown as born in year -54 in Table 8 , there is a 0.4 percent loss for the income class 3 , a 1 percent loss for middle income classes, and a 1.5 percent loss for the highest income class. For 25 -year olds, the welfare losses are more uniform across income classes, ranging from 2 to 3 percent.

\section{Dropping out: The On-Going-with-Floor Liability}

Dropping out of Social Security involves three steps: a) allow workers to drop out of social security, thereby eliminating both the payroll tax they face as well as any claims to future social security benefits; b) collect payroll taxes and paying benefits to those who do not drop out; and c) use general revenue to pay for the gap between payroll taxes collected and benefits paid. Workers will choose to drop out of Social Security if their present value of future Social Security taxes exceeds the present value of their future benefits. Dropping out impacts the future time path of prices and so, in general equilibrium, the drop out decision for each worker to depends on the choice of all other workers. The corresponding Nash equilibrium is found by iterating until all the decisions for each worker (including lifecycle consumption and leisure choices) remain unchanged.

We again consider two alternative taxes to supplement social security's revenue: income taxation with the tax base reductions noted earlier, and consumption taxation. Since all agents eventually choose to drop out of social security in the final steady state, those taxes are purely transitional. As a result, all of the dropping out experiments converge to the same final steady state — and the same steady state as the traditional experiments reported earlier, a fact that facilitates the comparison of transition paths. 


\section{$\underline{\text { Participation }}$}

The solid lines in the top panel of Figure 5 show those generations by income class who participate in the new privatized system - that is, drop out of social security- for the income tax finance case. ${ }^{11}$ All agents younger than 25 years of (real-life) age drop out as do all future agents. The participation lines therefore are not continued past transitional year 50 for the sake of resolution.

The decision to drop out differs both inter-generationally and intra-generationally. Intergenerationally, many living agents, especially older people, stay with social security because they face little future payroll taxes relative to future benefits. Many young workers, however, choose to drop out because the present value of their future taxes exceeds their benefits. Intra-generationally, a poor agent is less likely to drop out of social security than a richer agent of the same age due to the progressive nature in which social security benefits are computed.

The biased nature of these drop out decisions might seemingly look like "adverse selection." Adverse selection is a primary reason why traditional plans to fundamentally reform the U.S. Social Security system require participation. However, it should be kept in mind that all truthful revelation mechanisms work by creating a selection bias in the contracts that agents select. To be sure, allowing for dropping out could lead to selection problems if Social Security continued to rely on payroll taxes levied on its participants as its only revenue source. In that case, dropping out, by those agents who owe Social Security more in future taxes than they will receive in future benefits, requires increasing the payroll tax on those who remain, causing more drop outs, ad infinitum, until no one remains. This tax spiral, though, is avoided herein by supplementing Social Security with funds from general revenue which allows the payroll tax rate to be chosen exogenously.

\footnotetext{
${ }^{11}$ The consumption tax finance case produces similar qualitative participation rates.
} 


\section{$\underline{\text { Macroeconomic and Welfare Effects }}$}

Consider first the income tax financing of benefits shown as Run 3. Compared with Run 1, which used income tax financing to pay for the shutdown liability under the traditional approach, Tables 3 - 7 shows that dropping out (Run 3) leads to a quicker rate of convergence. Whereas the capital stock is 5 percent smaller after 10 years under the traditional scheme, it is only 2.5 percent smaller under dropping out. The reason is that the traditional method investigated earlier pays off the entire shutdown liability. The dropping out approach pays off only the on-going-with-floor liability and so a smaller burden is passed to unborn generations and convergence is quicker.

Notice that the dropping out approach also does a moderately better job at protecting the welfare of the initial elderly, shown as being born in year -54 in Table 8. (We discuss the initial middle-age agents below.) The welfare of this age group is about one half a percentage point higher under dropping out relative to the traditional approach. Because the elderly receive the same Social Security benefit under both approaches, the reasons for the differences stem from the tax side. First, the smaller liability assumed under the dropping out approach generates smaller income taxes, and so interest income earned by the elderly is taxed at a smaller rate. Second, the dropping out method relies relatively more heavily on the wage tax base during the transition since it continues to collect some revenue from payroll taxes from those who remain in Social Security. In contrast, income taxation is used to fully pay for the transition in the traditional approach. The dropping out plan therefore puts more emphasis on wages and salaries than interest income, the latter of which is the most important source of income for the elderly.

Now consider consumption tax financing of benefits shown as Run 4. Compared with Run 2, which used consumption tax financing to pay for the shutdown liability under the traditional approach, Run 4 shows that the rate of convergence is similar for both approaches. Despite the larger liability, the reliance on a consumption tax under the traditional approach means that the initial 
elderly and middle-age workers near retirement with lots of wealth are hit the hardest by the consumption tax. A consumption tax is a combination of a wage tax along with a lump-sum wealth levy on existing wealth holders since existing wealth holders must now pay taxes when they consume out of their savings. This large wealth levy reverses much of the extra liability that is being passed to future generations associated with the traditional approach.

However, the partial reversal is far from perfect because the value of the wealth levy is proportional to an agent's level of wealth instead of being proportion to an agent's net present value of Social Security. Notice from Table 8 that except for income class 1 who have virtually no wealth, the loss in utility for the initial elderly, shown as born in year -54, is almost 50 percent larger under the traditional approach relative to the drop out approach. The drop out approach again better protects the initial elderly by better matching what the government pays out in transitional benefits relative to the value that each agent places on actually remaining in Social Security.

\section{Reducing the Payroll Tax Rate to Half the Current Level}

Not surprisingly, the dropping out approach does not benefit everyone relative to the traditional method. Dropping out leads to larger welfare losses for middle-age agents across the entire income distribution. For example, dropping out decreases the welfare for 25 -year olds (46 in real life) in income classes 6 through 9 by almost one half percentage point more than the traditional approach when income tax financing is used (compare Run 3 with Run 1), and by almost a full percentage point with consumption tax financing (compare Run 4 with Run 2). The reason is that these middle-age agents tend to not drop out (Figure 5, top panel) and so, therefore, they pay both the existing payroll tax as well as higher income or consumption taxes that finances the transition.

Runs 5 and 6 consider a variation of the dropping out plan in which the payroll tax is reduced to one-half of its present law value. Run 5 uses income tax financing like Run 3 except with a 
reduced payroll tax; Run 6 is like Run 4 which uses consumption tax financing. By raising less payroll tax revenue from middle-age workers, more of the transitional pain is shifted in Runs 5 and 6 to the tails of the age distribution by increasing even more either the income or consumption tax. More pain is shifted to both older workers, who pay little or no payroll taxes during retirement, and to younger workers who pay little or no payroll taxes after they drop out.

Comparing Run 5 with Run 3 shows that middle-age workers (born in year - 25) are now relatively much better off under the new reduced payroll tax, by as much as 1.5 percentage points of remaining lifetime utility. Moreover, comparing Run 5 with Run 1 shows that middle-age agents now fare better relative to the traditional approach, by as much as 1 percentage point.

Interestingly, hardly detectable traces of extra burden are shifted to the initial elderly born in year - 54 under the reduced payroll tax (compare Runs 3 and 5, and Runs 4 and 6). Moreover, the initial elderly still fair better under the dropping out approach with the reduced payroll tax rate relative to the traditional method (compare Runs 1 and 5, and Runs 2 and 6). The reason is that the decrease in the payroll tax rate causes fewer people to drop out initially, as shown in the bottom panel of Figure 5. The payroll tax revenue therefore drops by only 20 percent in going from Run 3 to Run 5 (equal to about 7 percent of the pre-privatization payroll tax revenue) instead of 50 percent which could be expected from the outset since the payroll tax rate is reduced by half. Only a small amount of additional general revenue is therefore needed initially. The decrease in the payroll tax rate slows down speed of dropping out, but eventually every future generations drops out. As a result, relatively more tax revenue is needed in the future. Halving the payroll tax rate, therefore, effectively pushes much of the transition burden to younger agents and future generations, many of whom benefit from system conversion. Notice, however, that the costs to each young worker at the time of the reform is only slightly larger because since they are more plentiful in supply and since the transitional burden is spread more evenly throughout time. Many of these workers are still better off under the dropping 
out approach relative to the traditional approach. The rate of convergence of the capital stock is only a little slower than the straight dropping out with no change in the payroll tax rate, but the rate of convergence is still faster than that corresponding to traditional participation.

So what is the cost of this good news? The dropping out approach with a reduced payroll tax rate reduces the gains to generations born in years 1 - 10, the first decade after conversion. However, each of those agents still receive a positive gain relative to no reform and so this burden shifting might be desirable. Similar results hold for consumption tax financing (Runs 2, 4, and 6).

\section{Conclusion}

A policy that allows people to drop out of social security would generate a truthful revelation equilibrium in which people reveal valuable private information about their skill level. As a result, the liability assumed by Social Security upon conversion to individual accounts is potentially much smaller than the "shutdown liability" assumed under the traditional conversion approach which does not use this valuable information. The dropping out approach, therefore, can produce more favorable macroeconomic and distributional outcomes. The actual relevance of the dropping out approach versus the traditional approach was demonstrated using a large-scale lifecycle simulation model that incorporates heterogeneous skill levels. It was shown that dropping out leads to quicker transition paths and can better protection of the welfare of the initial elderly relative to the traditional method.

The usual "no free lunch" principal applicable to the privatization literature still applies to all of the experiments herein. In particular, unlike fundamental tax reform, changes in debt or social security liabilities do not directly change the relative price of consuming today versus tomorrow. As a result, changes in debt or social security liabilities cannot be pareto improving even with a hypothetical lump-sum transfer mechanism. Any wealth-equivalent increase in utility to one generation or income class stemming from changes in debt or social security liabilities must be offset 
by an equal decrease in present value to another generation or income class. Of course, social security reform can be packaged with a reform to the tax system that is pareto improving; but all the efficiency stems from tax reform which can be accomplished independently of social security reform.

But while decreasing a social security system's liability is not pareto improving, increasing the system's liability does not improve efficiency either if the economy is not over-capitalized. The dropping out approach does a better job of matching what the system owes each worker upon conversion to how much each worker actually values remaining in social security. Better matching avoids transferring an additional burden to future generations that arises from the inability of the traditional conversion approach to accurately measure the true value of social security for each participant (due to asymmetric information). To be sure, using a consumption tax to finance the transition path under the traditional approach reverses much of this extra inter-generational transfer. But this approach does not well approximate the more accurate matching of liabilities to net social security benefits achieved via the dropping out approach since a consumption tax wealth levy hits the initial elderly hard, creating a very different intra-generational resource distribution. 


\section{References}

Altig, David and Jagadeesh Gokhale. "Social Security Privatization: One Proposal." The Cato Project on Social Security Privatization, SSP No. 9, 1997.

Altig, David, Alan Auerbach, Larry Kotlikoff, Kent Smetters, Jan Walliser. "Simulating U.S. Tax Reform." NBER Working Paper No. 6246, 1997.

Arrau, Patricio and Klaus Schmidt-Hebbel. "Macroeconomic and Intergenerational Welfare Effects of a Transition from Pay-as-You-Go to Fully Funded Pensions," Policy Research Dept., Macroeconomics and Growth Division, Washington, D.C.: World Bank, Washington, D.C. 1993. Auerbach, Alan J. and Laurence J. Kotlikoff. Dynamic Fiscal Policy, Cambridge, England: Cambridge University Press, 1987.

Auerbach, Alan J., Laurence J. Kotlikoff, Robert P. Hagemann, and Giuseppe Nicoletti, "The Economic Dynamics of an Ageing Population: The Case of Four OECD Countries," OECD Economic Studies, Spring 1989, 51-96.

Auerbach, Alan J. "Tax Reform, Capital Allocation, Efficiency, and Growth," in: Henry Aaron and William B. Gale (eds.), Economic Effects of Fundamental Tax Reform, Washington, D.C.: The Brookings Institution. 1996.

Feldstein, Martin. "Toward a Reform of Social Security." Public Interest, No. 40 (Summer, 1975), pages $75-95$.

_. "Would Privatizing Social Security Raise Economic Welfare?" NBER Working Paper Series, Working Paper 5281, 1995.

and Andrew Samwick. "The Economics of Prefunding Social Security and Medicare Benefits." in B. Bernanke and J. Rotemberg (eds.) NBER Macroeconomics Annual 1997. Cambridge: MIT Press, 115-148.

Fullerton, Don and Diane Lim Rogers. Who Bears the Lifetime Tax Burden?, Washington, D.C.: The Brookings Institution. 1993.

Geanakopolis, John, Olivia Mitchell, and Stephen Zeldes. "Social Security's Money's Worth." Prospects for Social Security Reform, Olivia S. Mitchell, Robert J. Myers and Howard Young Editors, University of Pennsylvania Press, Philadelphia, PA: 79 - 151.

Gustman, Alan and Thomas Steinmeier. "Privatizing Social Security: First Round Effects of a Generic, Voluntary Privatizes U.S. Social Security System." NBER Working Paper No. 5362, 1995.

Huang, He, Selo İmrohoroğlu and Thomas Sargent. "Two Computational Experiments to Fund Social Security." Macroeconomic Dynamics, February 1997, 1(1): 7-44.

Kotlikoff, Laurence J. "Privatizing Social Security: How It Works and Why It Matters," in: James M. Poterba (ed.), Tax Policy and the Economy, vol. 10, Cambridge, Mass.: MIT Press, 1996. 
Kotlikoff, Laurence J., Kent Smetters, and Jan Walliser. "Privatizing U.S. Social Security - A Simulation Study," forthcoming in: Klaus Schmidt Hebbel (ed.), Pension Systems: From Crisis to Reform, Washington, D.C.: The World Bank, 1997.

Menchik, Paul L. and Martin David. "The Incidence of a Lifetime Consumption Tax," National Tax Journal, vol. XXXV, 1982, pp. 189-203.

Slemrod, Joel and Jon Bakija. Taxing Ourselves: A Citizen's Guide to the Great Debate over Tax Reform, MIT Press: Cambridge, MA, 1996. 


\section{Appendix}

\section{The Non-Social Security Tax System}

The tax system is designed to approximate the salient aspects of the 1996 U.S. (federal, state, and local) tax and transfer system. It features a hybrid tax system (incorporating wage-income, capital-income, and consumption tax elements) and payroll taxation for the Social Security and Medicare programs. To adjust for tax evasion, we reduce income taxes by 2.6 percentage points. This adjustment is consistent with the degree of tax evasion reported in Slemrod and Bakija (1996). In the various alternative tax structure experiments we assume that evasion reduces the post-reform tax base (income net of deductions and exemptions) by the same percentage as before the reform. Thus, the level of tax evasion falls when the tax base shrinks.

We approximate the hybrid current U.S. tax system by specifying a progressive wage-income tax, a flat capital-income tax, a flat state income tax, and a flat consumption tax.

Wage Income Taxation. The wage-income tax structure has four elements: 1) progressive marginal rate derived from a quadratic approximation to the 1996 federal statutory tax rates for individuals, 2) a standard deduction of $\$ 4000$ and exemptions of $\$ 5660$ (assuming 1.2 children per agent, consistent with the model's population growth assumption), 3) Itemized deductions — applied only when they exceed the amount of the standard deduction - that are a positive linear function of income estimated from data reported in the Statistics of Income, ${ }^{12}$ and 4) Earnings-ability profiles that are scaled up to incorporate pension and non-pension components of labor compensation. ${ }^{13}$

\footnotetext{
12 The data used in this estimation was taken from all taxable returns in tax year 1993. The function was obtained by regressing deductions exclusive of mortgage interest expense on the midpoints of reported income ranges. (The deduction of interest expense on home mortgages was included in our calculation of the capital-income tax rate, as we will subsequently describe.) The regression yielded a coefficient of 0.0755 with an $\mathrm{R}^{2}$ equal to 0.99 .

${ }^{13}$ Benefits as a function of adjusted gross income were kindly provided by Jane Gravelle of the Congressional Research Service and Judy Xanthopoulos of the Joint Committee on Taxation, respectively. Based on this information we regressed total benefits on AGI. The regression yielded a coefficient of 0.11295 with an $\mathrm{R}^{2}$ equal to 0.99 . In defining the wage-tax base, we therefore exempt roughly 11 percent of labor compensation from the base calculations.
} 
The model's initial economy-wide average marginal tax rate on wage income is 21 percent, obtained from the NBER's TAXSIM model reported in Auerbach (1996). The average wage-income tax rate equals 12.1 percent. For all individuals in the highest lifetime income class (group 12), the average effective marginal tax rate on labor income is 28.6 percent. The highest realized marginal tax rate is 34 percent. For lifetime income class 6-whose members have peak labor earnings of about $\$ 35,000$ - the average tax rate and average marginal tax rate are 10.6 and 20.0 percent, respectively. For the poorest income class 1 , the corresponding rates are zero and 5.5 percent. ${ }^{14}$

Capital Income Taxation. Following Auerbach (1996), we assume that income from residential and non-residential capital are taxed at flat rates of 6 percent and 26 percent, respectively. Given the roughly equal amounts of these two forms of capital, the effective federal marginal tax rate on total capital income is 16 percent. However, this rate applies only to new capital. Existing capital faces a higher tax rate which, given depreciation schedules, is estimated to be 20 percent. We model this gap by assuming that all capital income faces a 20 percent tax, but that 20 percent of new capital may be expensed, thereby generating a 16 percent effective rate on new capital.

State Income Taxation. In addition to the federal taxation, both capital and wage income are subject to a proportional state income tax of 3.7 percent. This value corresponds to the amount of revenue generated by state income taxes in 1996 divided by national income.

Consumption Taxation. Consumption taxes in the initial steady state reflect two elements of the existing tax structure. First we impose an 8.8 percent tax on consumption expenditures consistent with values reported in the National Income and Product Accounts on indirect business and excise revenues. However, because contributions to both defined benefit and defined contribution pension plans receive consumption tax treatment, we levy an additional 2.5 percent tax

\footnotetext{
${ }^{14}$ The average marginal rate for people with the lowest income exceeds zero due to positive shadow tax rates in peak earnings years.
} 
on household consumption goods expenditures to account for the indirect taxation of labor compensation in the form of pension benefits (Auerbach 1996). This 2.5 percent tax replaces the wage tax that otherwise would apply to labor compensation in the form of fringe benefits.

\section{Solving the Model}

The model solves for the full rational-expectations dynamic (Nash) equilibrium with a Gauss-Seidel algorithm. The calculation starts with a guess for certain key variables and then iterates on those variables until a convergence criterion is met. The identifying restrictions of the model are used to compute the remaining economic variables as well as the updates for the iterations. The solution involves several steps and inner loops that solve for household-level variables before moving to an outer loop which solves for the time-paths of aggregate variables and factor prices. Since the decision to drop out by any agent will be affected by the exact time path of factor prices — which, in turn, is affected by the dropping out decisions of other agents - the dropping out choice is determined endogenously for each agent. The solution algorithm iterates until each agent, given the prevailing path of factor prices, prefers his/her intertemporal allocation of consumption and leisure and his/her decision whether to drop out.

The household optimization problem is subject to the constraint that leisure not exceed the endowment of time (equation (2)). For those households who would violate the constraint, the model calculates shadow wage rates at which they exactly consume their full-time endowment.

The household's budget constraint is kinked due to the tax deductions applied against wage income. A household with wage income below the deduction level faces marginal and average tax rates equal to zero. A household with wage income above the deduction level faces positive marginal and average tax rates. Due to the discontinuity of the marginal tax rates, it may be optimal for some households to locate exactly at the kink. Our algorithm deals with this problem as follows. We 
identify households that choose to locate at the kink by evaluating their leisure choice and corresponding wage income above and below the kink. We then calculate a shadow marginal tax rate from the first-order conditions that puts those households exactly at the kink. This procedure generates optimal forward-looking leisure and consumption choices for all periods of life.

The payroll tax ceiling introduces additional complexity by creating a non-convexity in the budget constraint. For those above the payroll tax ceiling, the marginal tax rate on labor falls to zero. We evaluate the utility on both sides of the non-convex section and put households on the side that generates highest utility.

The sequence of calculations is as follows. An initial guess is made for the time-paths of these aggregate variables as well as for the shadow wage rates, shadow tax rates, endogenous tax rates, the separate OASI / DI / HI payroll tax rates, and the Social Security and Medicare wealth levels. The corresponding factor prices are calculated along with the forward-looking consumption, asset and leisure choices for all income classes in each current and future cohort. Shadow wages and shadow taxes are calculated to ensure that the time endowment and the tax constraints discussed above are satisfied. Households' labor supply and assets are then aggregated by both age and lifetime income class at each period in time. This aggregation generates a new guess for the timepaths of the capital stock and labor supply. The tax rate which is endogenous for the particular simulation, is updated to meet the revenue-neutrality requirement. The payroll tax is also updated to preserve the pay-as-you-go financing of OASI and HI benefits. ${ }^{15}$ The tax rate for DI benefits is also updated. The algorithm iterates until the capital stock and labor supply time-paths converge.

\footnotetext{
${ }^{15}$ Note that the Social Security replacement rate and absolute level of Medicare benefits are exogenous.
} 


\section{Figure 1}

\section{The US Replacement Rate as a Function of Average Indexed Yearly Earnings, $R(\cdot)$, for a Single Person Retiring in 1996:}

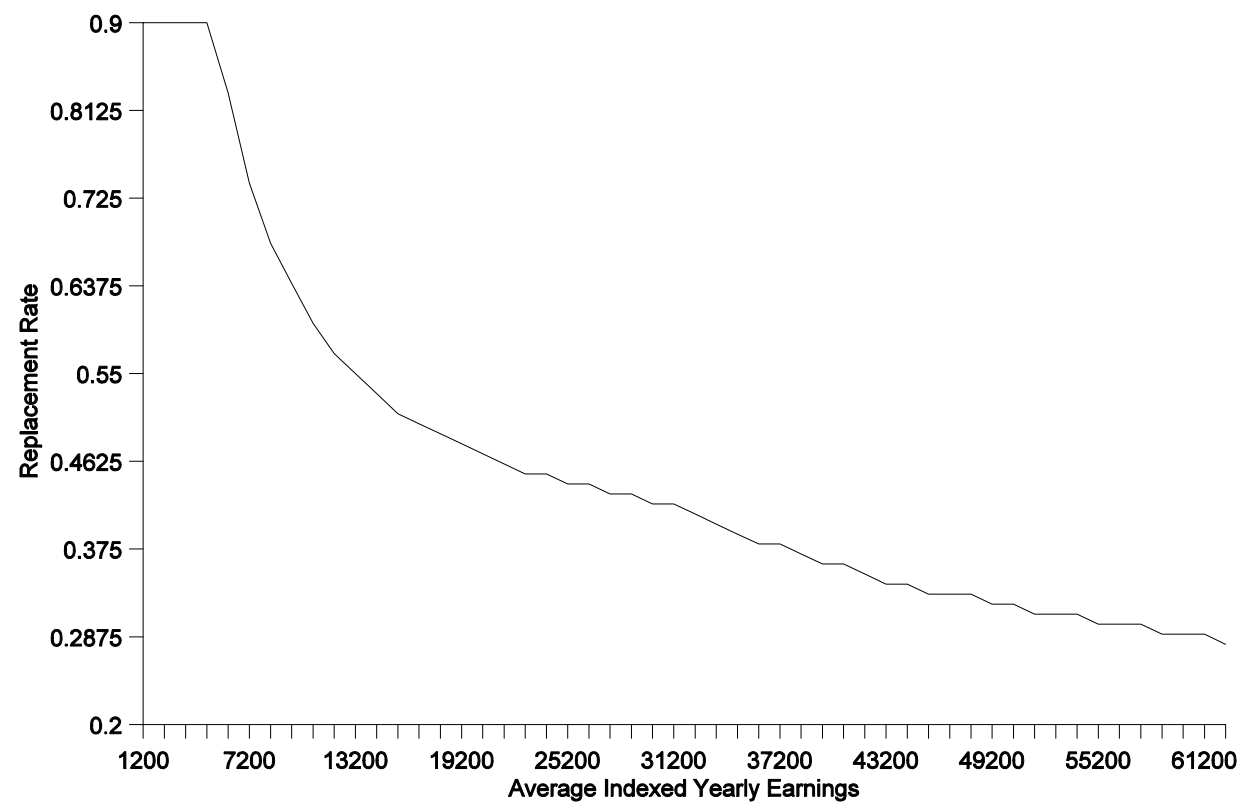

Notes: Replacement rate computed using the statutory formula for a person turning age 62 in 1996 . The monthly benefit equals 90 percent of first $\$ 437$ of covered Average Indexed Monthly Earnings ( $A I M E$ ) plus 32 percent of the next \$2,198 plus 15 percent above $\$ 2,635$. AIME converted to Average Indexed Yearly Earnings $(A I Y E)$ by multiplying times 12 . Replacement rates for single worker with retired spouse equals $1.5 \cdot R(\cdot)$. 
Figure 2

Effective Marginal Social Security Tax Rates by Age and Income Class

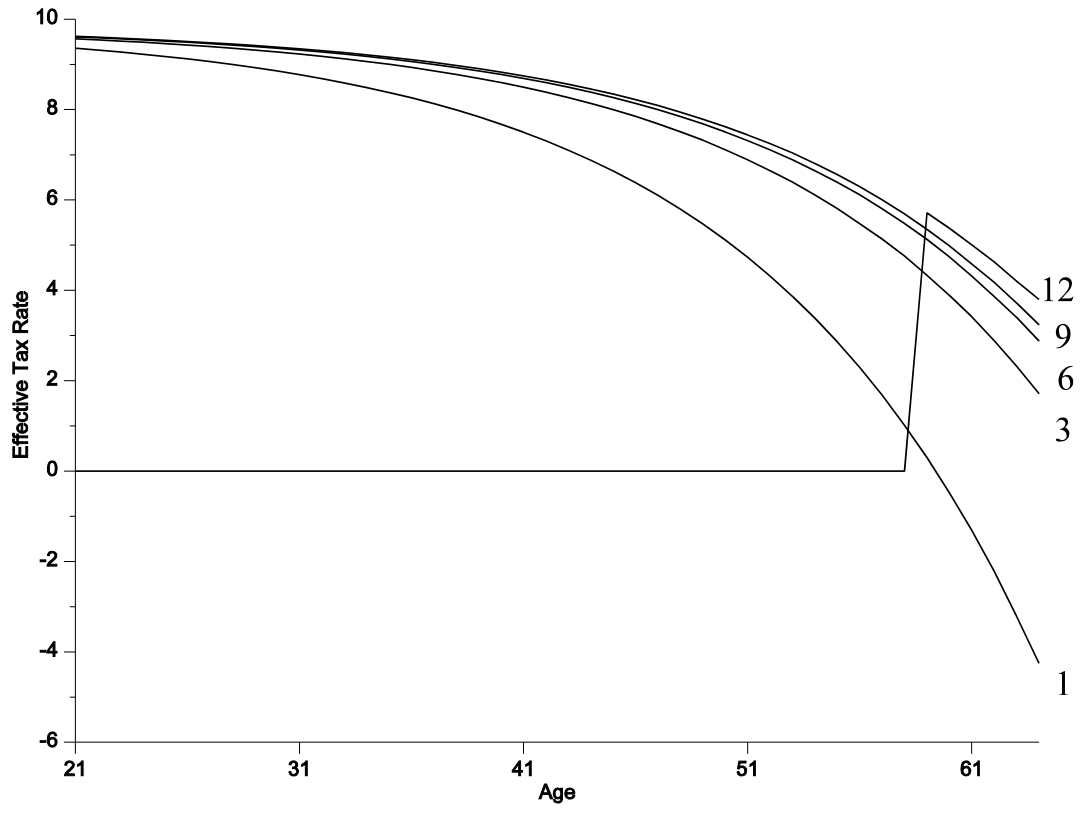


Traditional Conversion: Recognizing the Shutdown Liability

Figure 3

Income Tax Finance of Transition

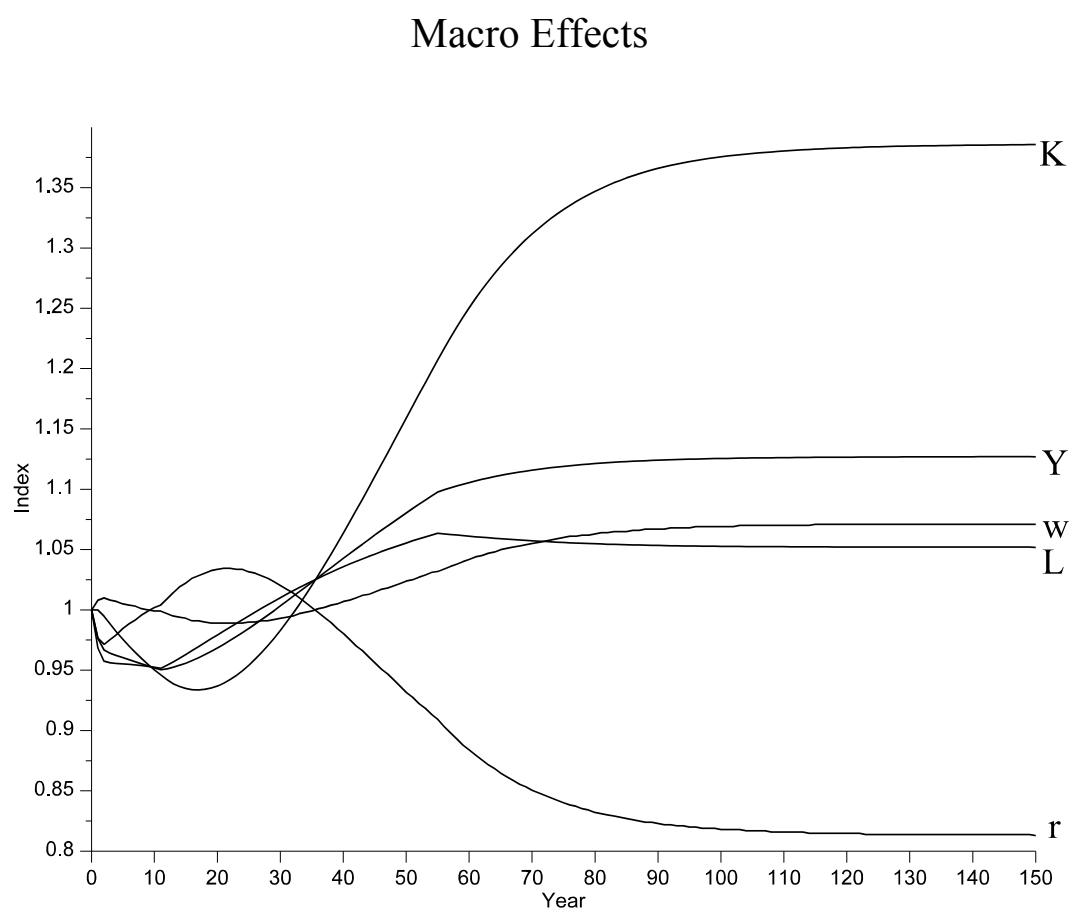

Remaining Lifetime Utility

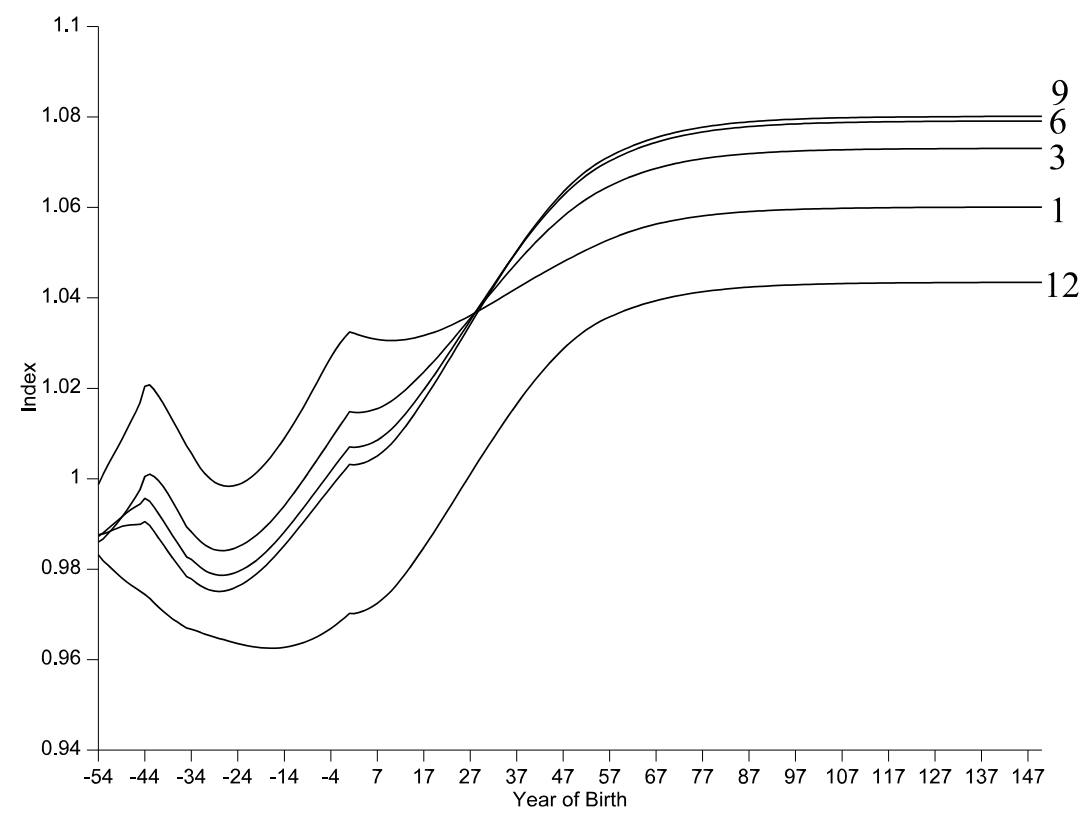


Traditional Conversion: Recognizing the Shutdown Liability

Figure 4

Consumption Tax Finance of Transition

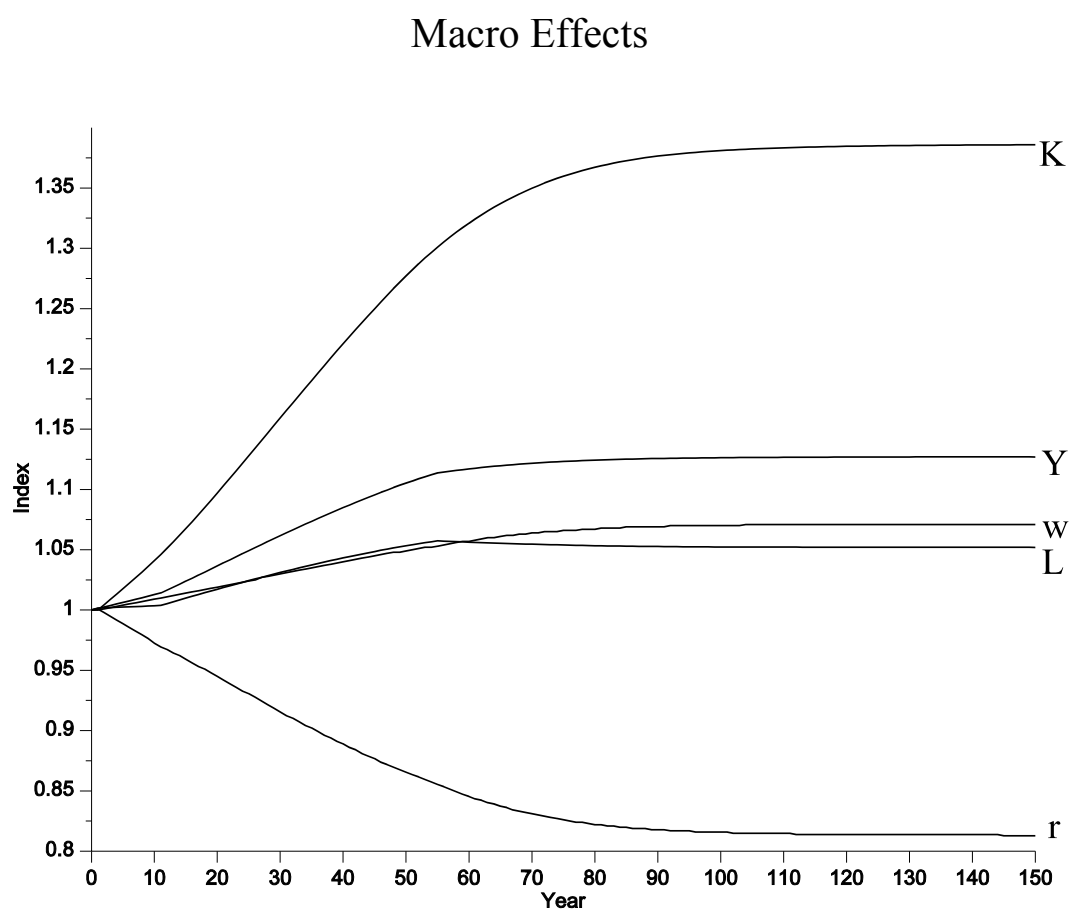

Remaining Lifetime Utility

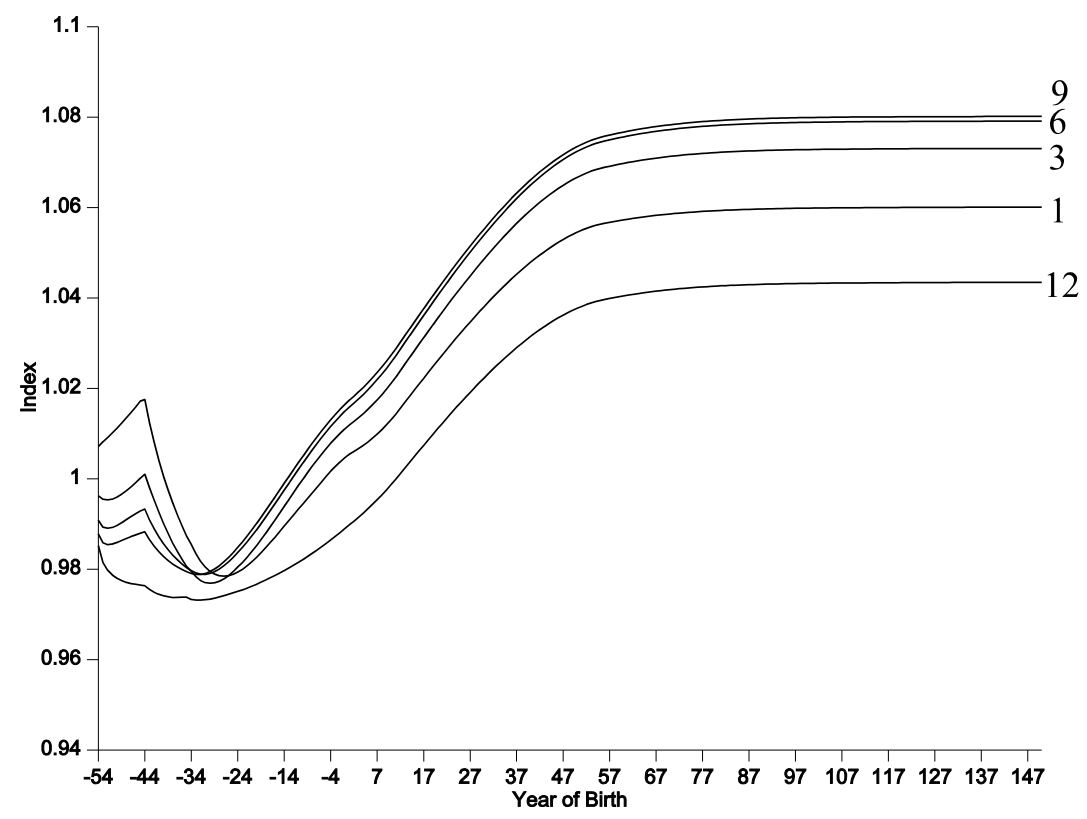


Figure 5

Who Drops Out of Social Security?

Income Tax Finance of Transition with New Payroll Tax Equal to Present Law Value (Solid line denotes generations that drop out)

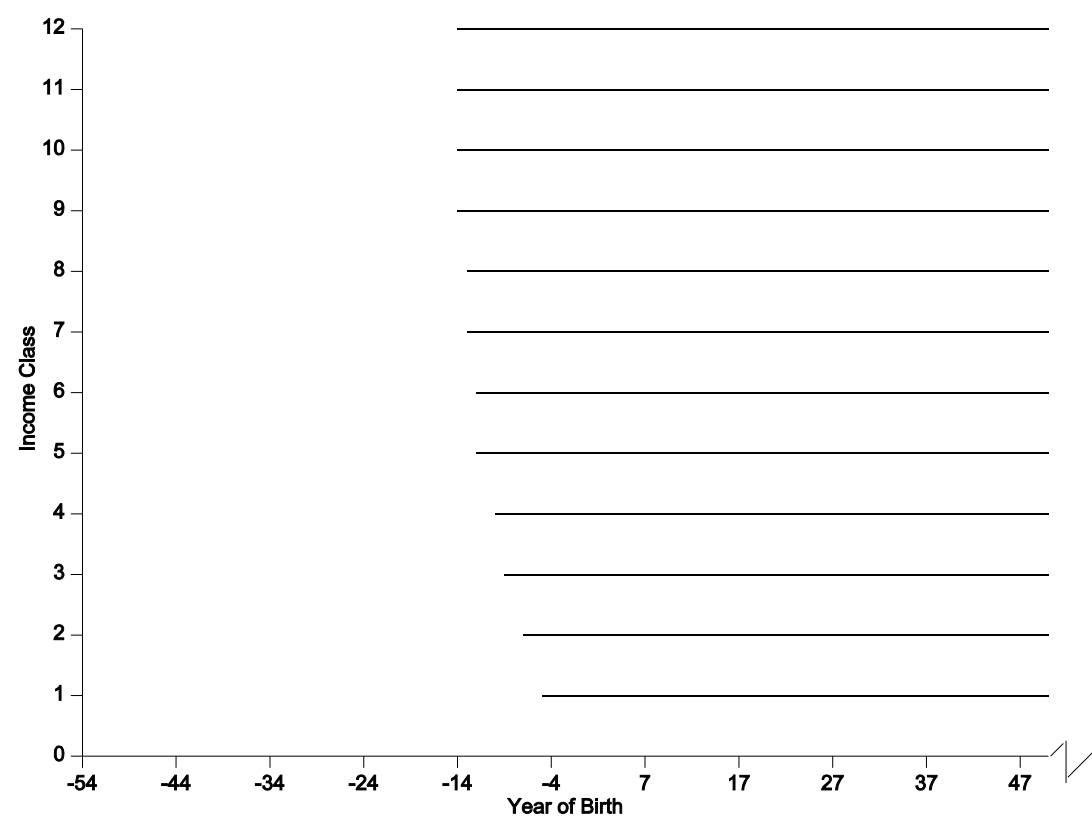

Income Tax Finance of Transition with New Payroll Tax Equal to One-Half Present Law Value (Solid line denotes generations that drop out) 


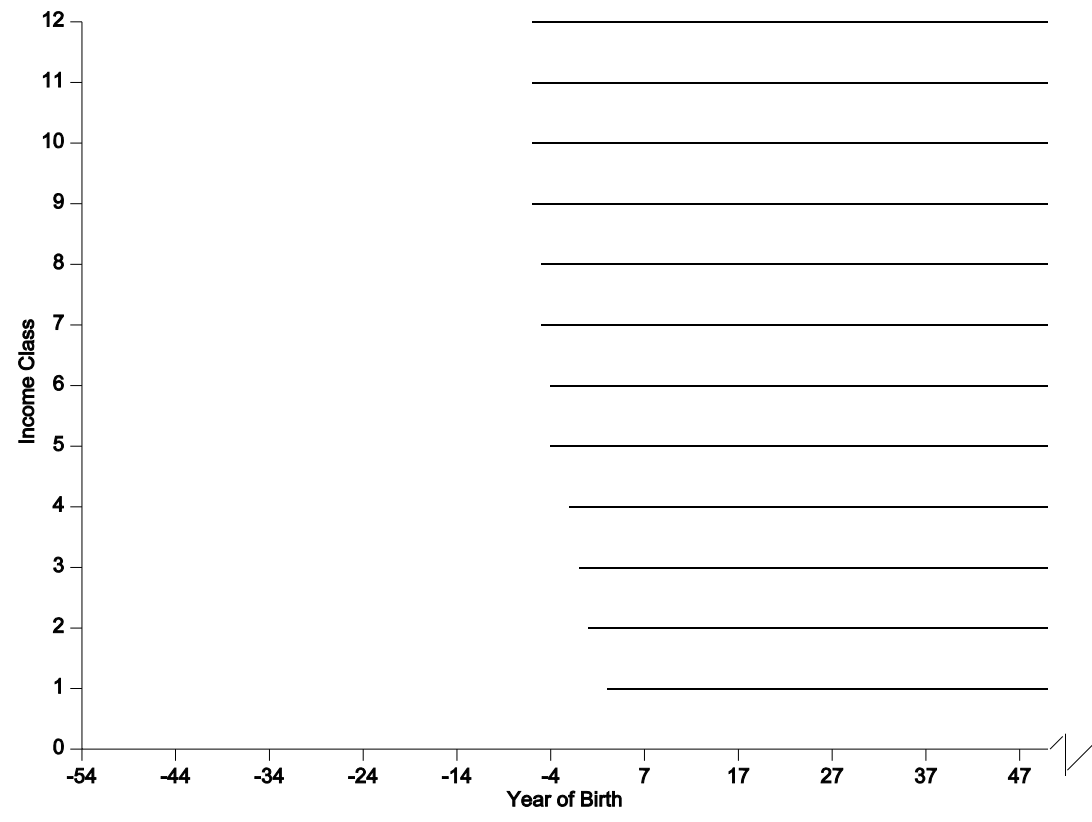


Dropping Out with New Payroll Tax Equal to Present Law Value

Figure 6

Income Tax Finance of Transition

Macro Effects

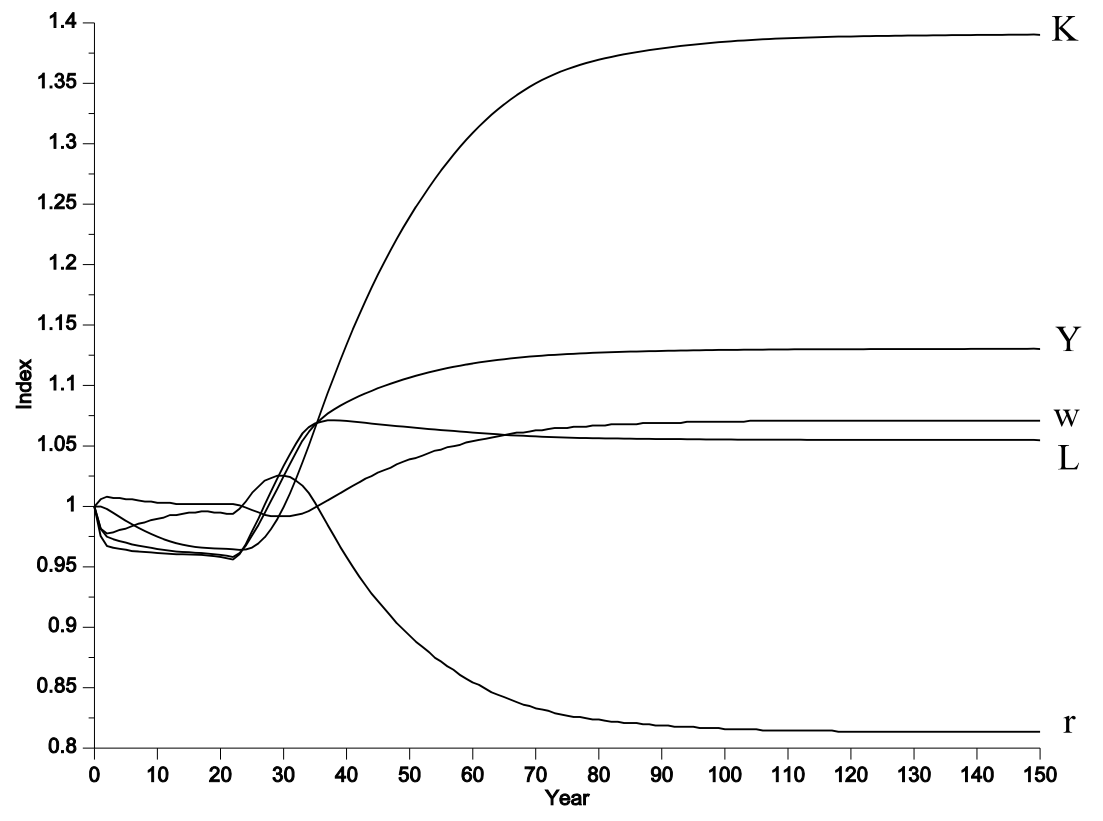

\section{Remaining Lifetime Utility}

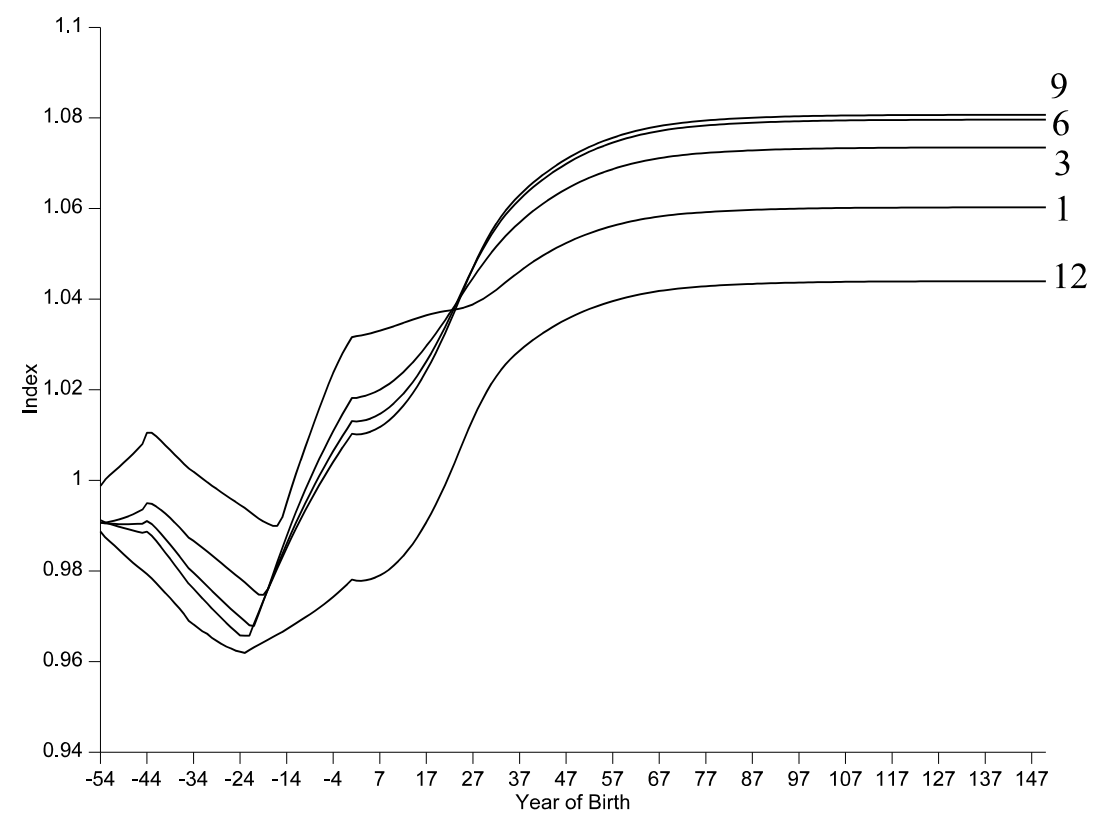


Dropping Out with New Payroll Tax Equal to Present Law Value

Figure 7

Consumption Tax Finance of Transition

Macro Effects

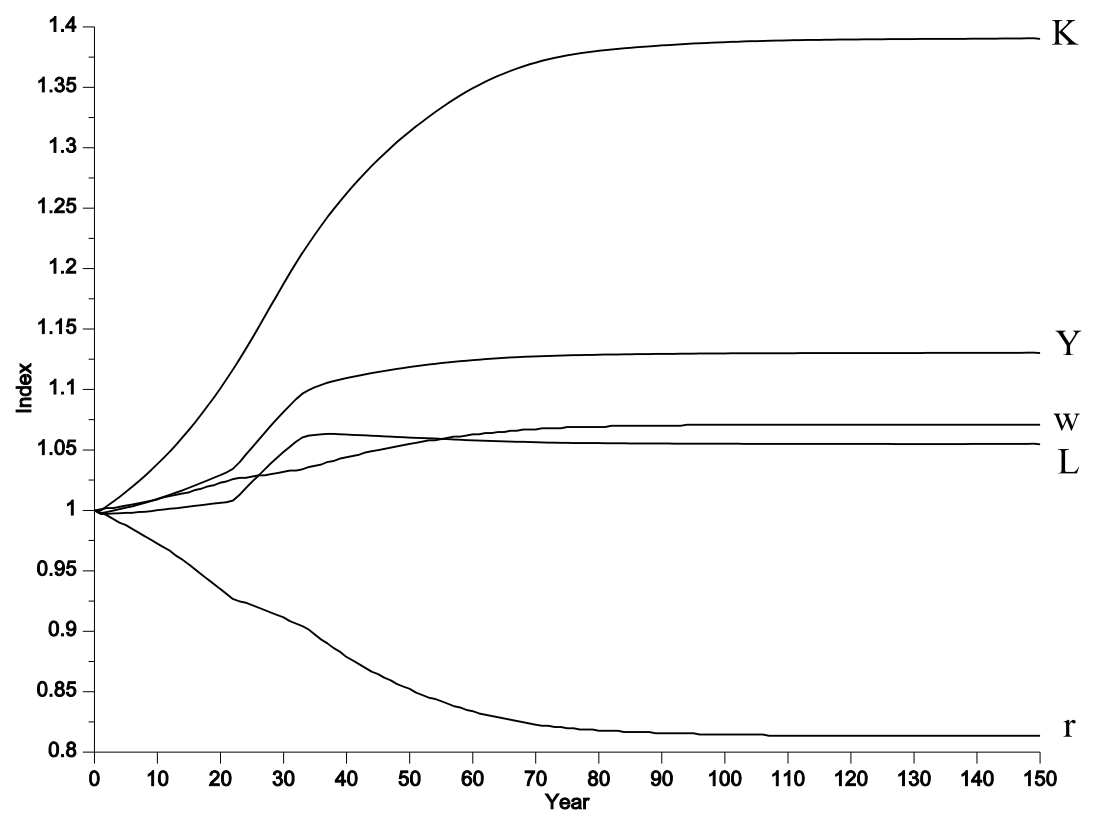

\section{Remaining Lifetime Utility}

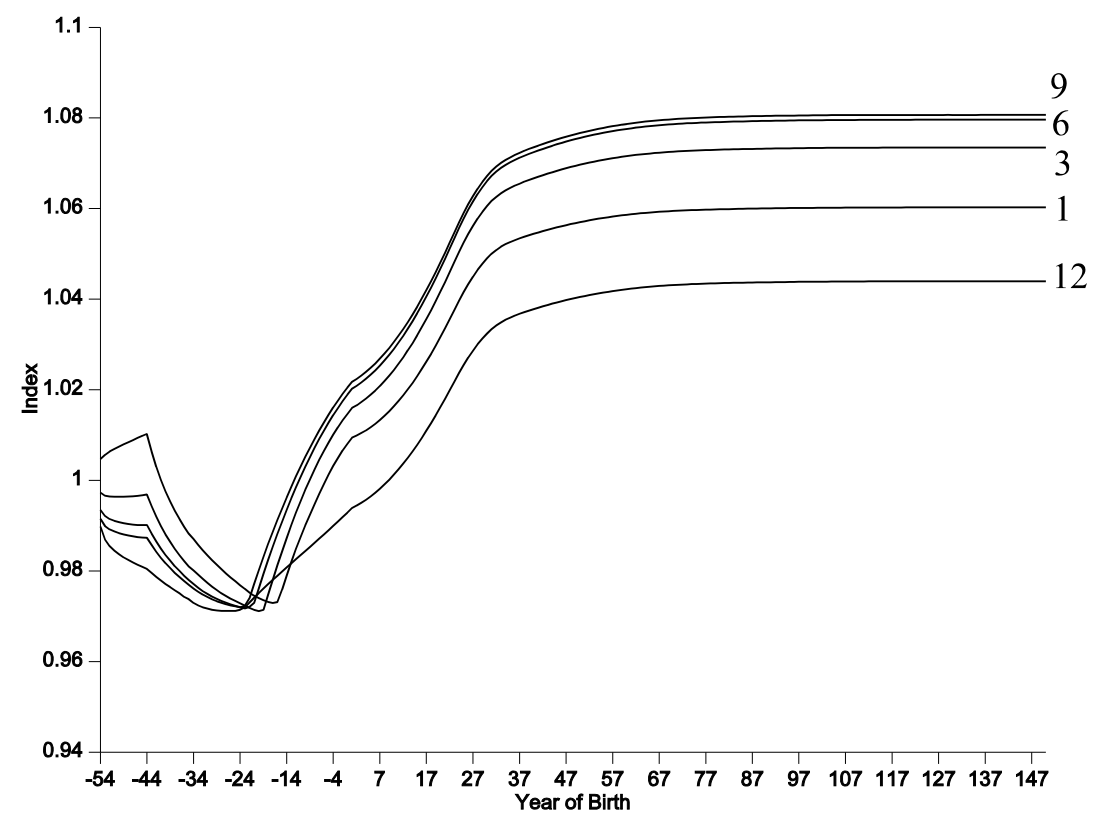


Dropping Out with New Payroll Tax Equal to One-Half of Present Law Value

Figure 8

Income Tax Finance of Transition

Macro Effects

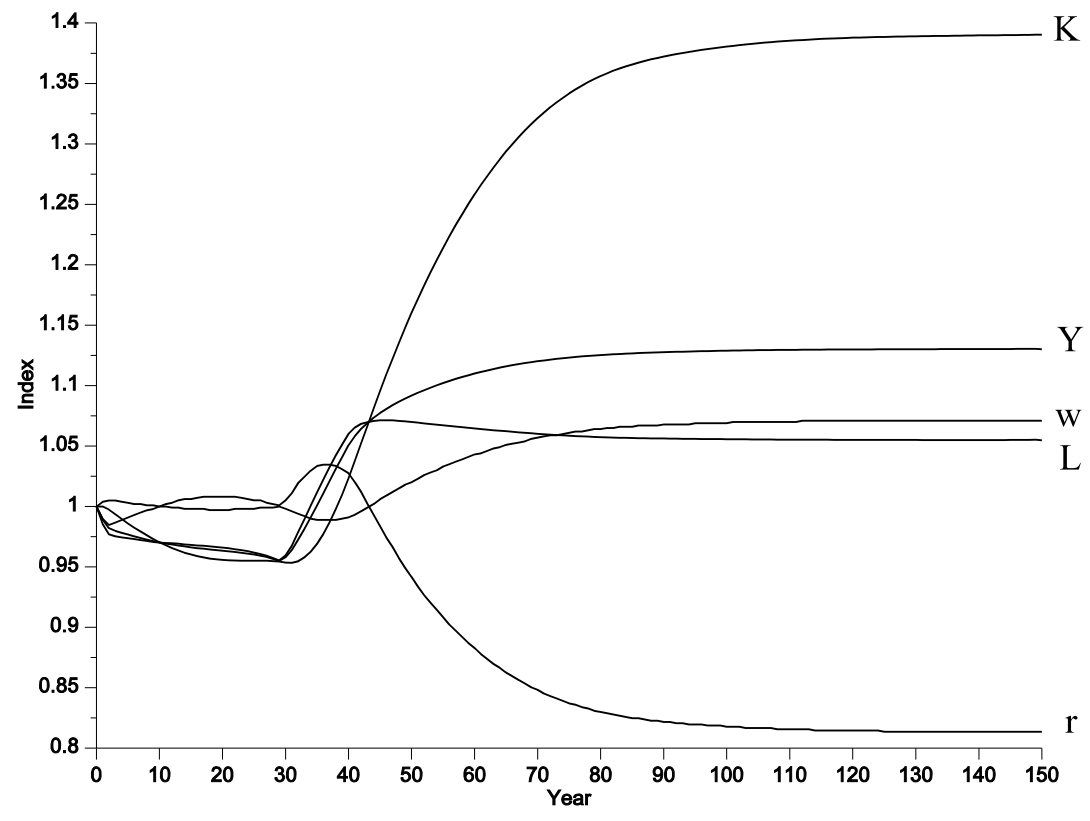

\section{Remaining Lifetime Utility}

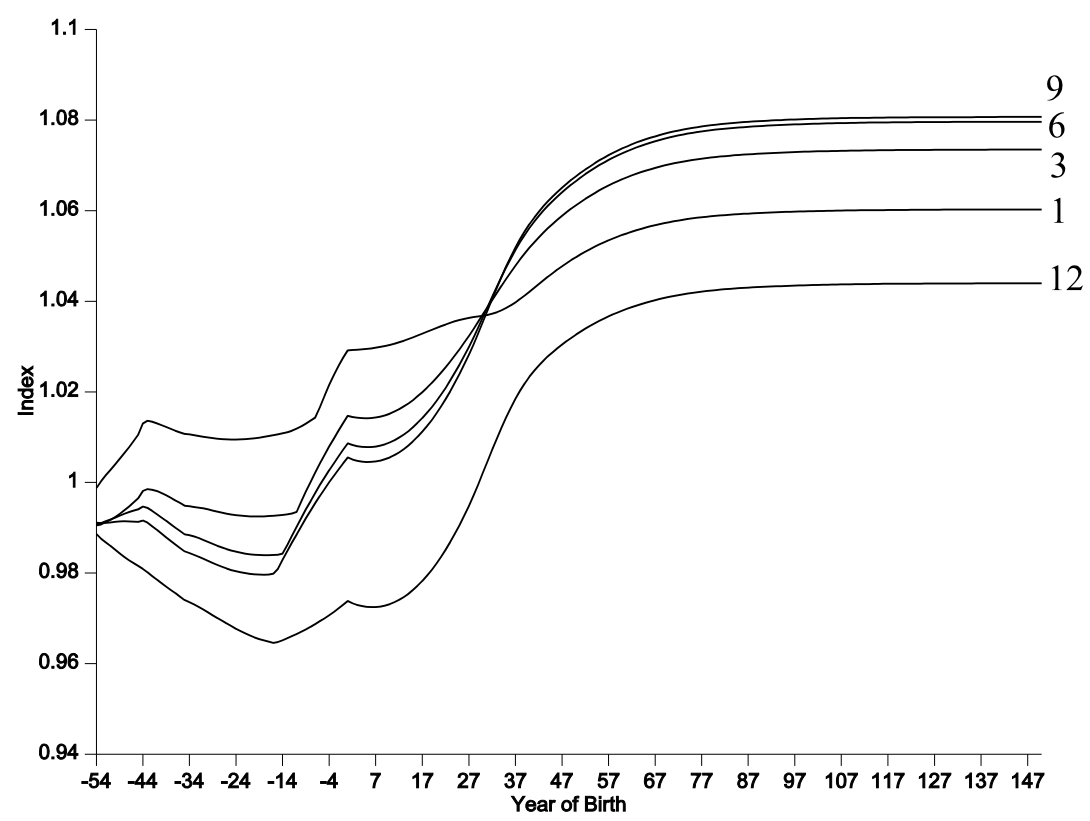


Dropping Out with New Payroll Tax Equal to One-Half of Present Law Value

Figure 9

Consumption Tax Finance of Transition

Macro Effects

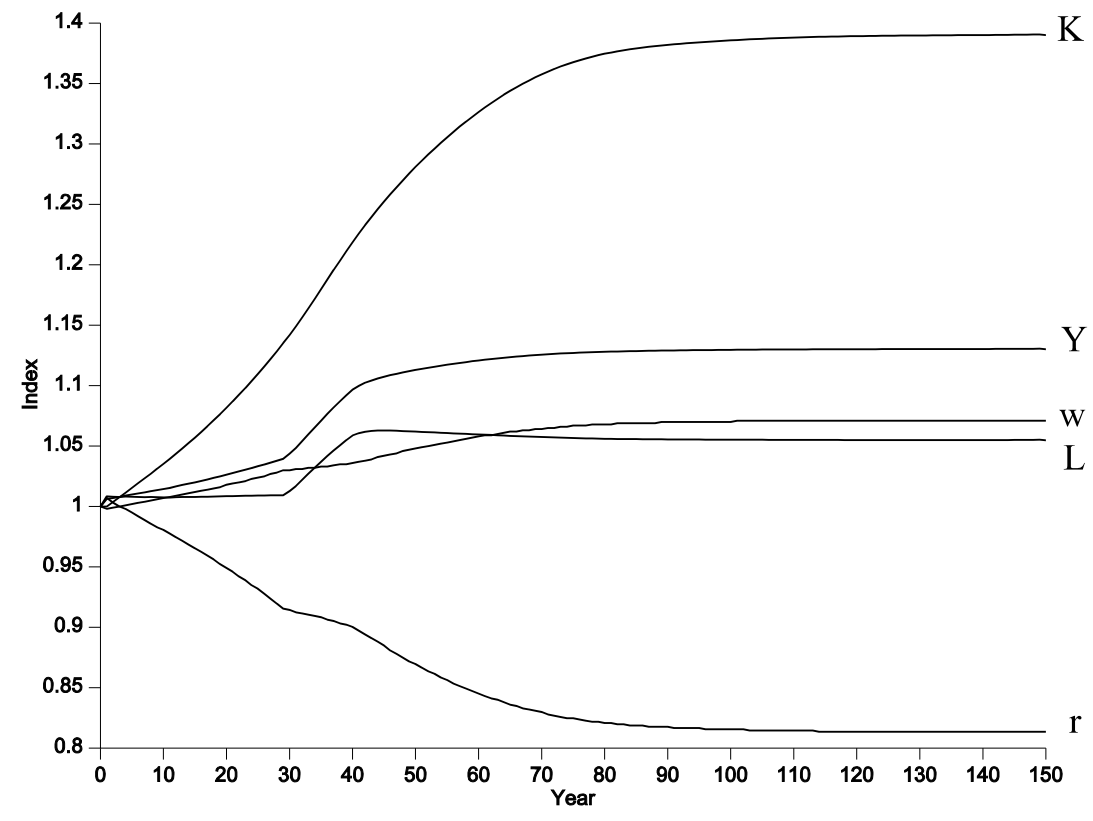

\section{Remaining Lifetime Utility}

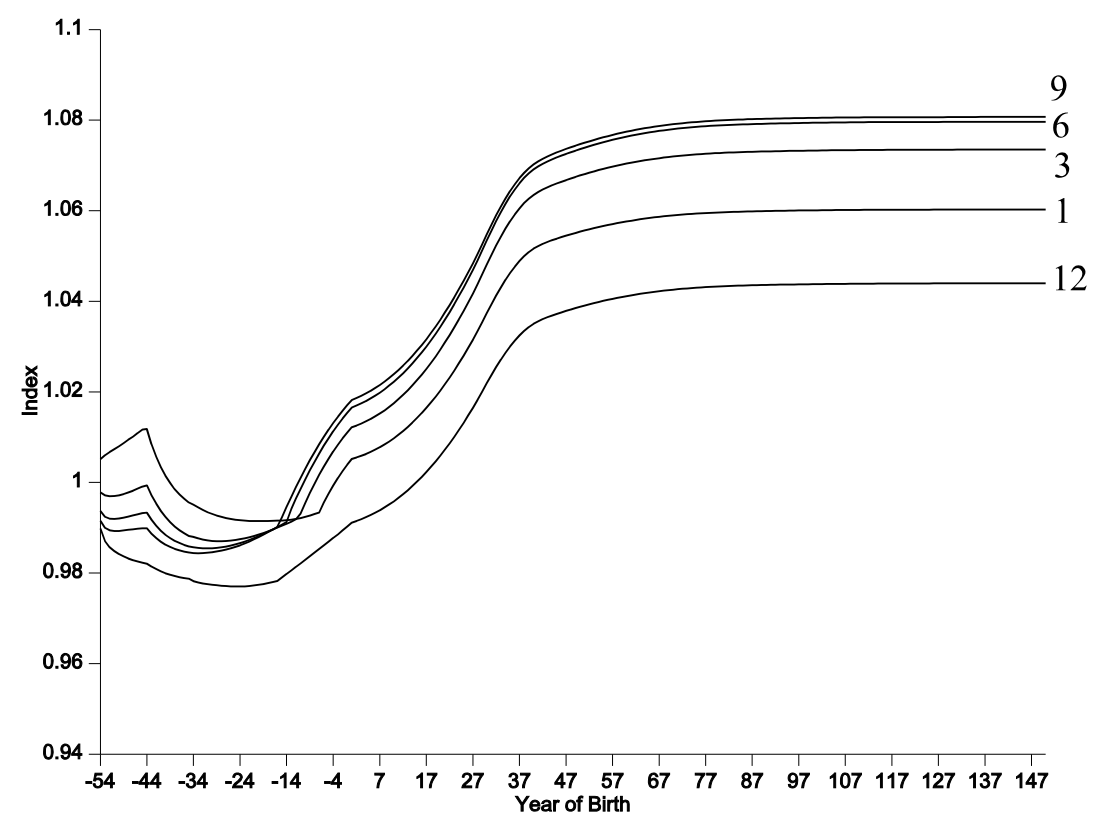




\begin{tabular}{|c|c|c|}
\hline Symbol & Definition & Value \\
\hline \multicolumn{3}{|c|}{ Preferences } \\
\hline$\alpha$ & Utility weight on leisure & 1.00 \\
\hline$\delta$ & Rate of time preference & 0.015 \\
\hline$\gamma$ & Intertemporal substitution elasticity & 0.25 \\
\hline$\mu^{\mathrm{j}}$ & Utility weight placed on bequests by income class $j$ & [1] \\
\hline$\rho$ & Intratemporal substitution elasticity & 0.80 \\
\hline \multicolumn{3}{|c|}{ HUMAN CAPITAL } \\
\hline$\varepsilon_{\mathrm{s}}^{J}$ & Productivity of agent in income class $j$ at age $s$. & [2] \\
\hline \multicolumn{3}{|c|}{ DEMOGRAPHICS } \\
\hline$n$ & Population growth & 0.01 \\
\hline$N$ & Number of children per adult, $(1+n)^{20}$ & 1.22 \\
\hline$\phi^{\mathrm{j}}$ & Fraction of agents of income class $j$ & [3] \\
\hline \multicolumn{3}{|c|}{ TECHNOLOGY } \\
\hline$\lambda$ & Technological change & 0.01 \\
\hline$b$ & Adjustment costs & 0.00 \\
\hline$\theta$ & Net capital share & 0.25 \\
\hline \multicolumn{3}{|c|}{ DEBT, TAXES, DEDUCTIONS IN INITIAL STEADY STATE } \\
\hline - & Debt service as fraction of National Income & 0.0350 \\
\hline - & Disability tax rate & 0.0185 \\
\hline - & Medicare tax rate & 0.0290 \\
\hline - & Progressive Social Security (OAI) replacement rate & [4] \\
\hline - & Social Security marginal tax-benefit linkage & 0.25 \\
\hline- & Payroll tax ceiling & $\$ 62,700$ \\
\hline $\mathrm{T}^{\mathrm{C}^{\prime}}$ & Proportional consumption tax & 0.113 \\
\hline $\mathrm{T}^{\mathrm{K}}$ & Proportional capital income tax & 0.20 \\
\hline $\mathrm{T}^{\mathrm{W}}(\cdot)$ & Kinked progressive wage tax with standard deduction & [5] \\
\hline $\mathrm{T}^{\mathrm{Y}^{\prime}}$ & State proportional income tax less evasion adjustment & 0.011 \\
\hline - & Itemized deductions proportional wage base & $0.0755^{[6]}$ \\
\hline - & Fringe benefits proportional wage base reduction & $0.1129^{[6]}$ \\
\hline$z$ & Expensing $^{[7]}$ & 0.20 \\
\hline
\end{tabular}


Footnotes:

[1] Calibrated endogenously in the initial state to match the level of bequests - as a fraction of mean national income - in Fullerton and Rogers (1993, Table 3-8), calibrated to 1996 dollars.

[2] See Appendix for estimation procedure.

[3] $\phi^{1}=0.02, \phi^{2}=0.08, \phi^{i}=0.10(3 \leq i \leq 10), \phi^{11}=0.08, \phi^{12}=0.02$

[4] The statutory progressive bendpoint formula for 1996, scaled up by a factor of 2 to account for the fact that other non-DI benefits (mainly spousal and survivors benefits) account for 50\% of all benefits paid (see 1996 OASDI Trustees Report, Table II.C7).

[5] The 1996 statutory tax function for a single individual with a deduction equal to $\$ 9661$ ( $\$ 4,000$ standard deduction, $\$ 2,550$ personal exemption and $\$ 2,550 \cdot N$ exemption for dependents).

[6] Total proportional base reduction above the standard deduction therefore equals 0.18845 .

[7] Deductions for new investment above economic depreciation and adjustment costs.

\section{Table 2. Key Endogenous Equilibrium Values for the Initial Steady State and the Corresponding Empirical Values}

\begin{tabular}{|c|c|c|c|}
\hline \multicolumn{2}{|c|}{ Model } & \multicolumn{2}{|r|}{ Empirical Estimate and Calculation } \\
\hline Concept & Value & Estimate & Calculation (using NIPA unless indicated) \\
\hline
\end{tabular}

\section{Composition of National InCOMe (PERCENT)}

$\begin{array}{lccl}\text { Personal Consumption } & 0.734 & 0.720 & \text { Personal consumption expenditures - housing services } \\ \text { Net Saving Rate } & 0.053 & 0.056 & \text { (National saving - capital consumption allowance)/NI } \\ \text { Government Consumption } & 0.214 & 0.212 & \begin{array}{l}\text { Consumption expenditures + gross investment for } \\ \text { federal (defense and nondefense) and state and local - } \\ \text { consumption of fixed capital }\end{array}\end{array}$

\section{TAX RATES AND GOVERNMENT REVENUE}
Avg. Marginal Wage Tax ${ }^{[1]}$
0.214
0.217 Auerbach (1996) based on the NBER TAXSIM model.
Government Revenue
0.239
0.239 Total receipts - contributions for social insurance - property taxes (state and local)
Social Security(OAI)Tax ${ }^{[2]} \quad 0.100$
0.1001996 tax rate is 10.52 which includes trust fund contributions equal to about 0.5 to 0.7 .

\section{CAPITAL-OUTPUT RATIO AND BEFORE-TAX INTEREST RATE}
Capital-Income Ratio
2.564
2.660
1993 current-cost net stock of fixed reproducible wealth
in the SCF - gov't owned fixed capital / 1993 NI
Before-Tax Rate of Return ${ }^{[3]} \quad 0.097$
0.093 The average from 1960-94 of the sum of interest, dividends, retained earnings and all corporate taxes to the replacement value of capital stock (Rippe, 1995).

Footnotes:

[1] Does not include the payroll tax.

[2] The combined OASDI-HI payroll tax therefore equals 0.147 which is close to the actual value of 0.153 and exactly equal to the correct value for the payroll tax after subtracting 0.006 for contribution to the trust fund.

[3] The social marginal rate of return (i.e., before corporate taxes). 
Table 3

Percentage Change in Capital Stock Relative to Steady State

\begin{tabular}{|c|c|c|c|c|c|c|c|}
\hline \multirow[b]{2}{*}{ Run } & \multirow{2}{*}{$\begin{array}{l}\text { Dropping } \\
\text { Out? }\end{array}$} & \multirow{2}{*}{$\begin{array}{l}\text { Finance } \\
\text { of Social } \\
\text { Security } \\
\text { Benefits }\end{array}$} & \multirow{2}{*}{$\begin{array}{c}\text { New } \\
\text { Social } \\
\text { Security } \\
\text { Tax Rate } \\
\end{array}$} & \multicolumn{4}{|c|}{ Year of Transition } \\
\hline & & & & 5 & 10 & 25 & 150 \\
\hline 1 & No & Y & $\mathrm{n} / \mathrm{a}$ & -2.4 & -5.0 & -4.6 & 39.0 \\
\hline 2 & No & $\mathrm{C}$ & $\mathrm{n} / \mathrm{a}$ & 1.8 & 4.1 & 12.8 & 39.0 \\
\hline 3 & Yes & $\mathrm{Y}$ & PL & -1.2 & -2.5 & -3.4 & 39.0 \\
\hline 4 & Yes & $\mathrm{C}$ & PL & 1.5 & 3.8 & 14.2 & 39.0 \\
\hline 5 & Yes & $\mathrm{Y}$ & $\mathrm{PL} / 2$ & -1.4 & -3.0 & -4.5 & 39.0 \\
\hline 6 & Yes & $\mathrm{C}$ & $\mathrm{PL} / 2$ & 1.5 & 3.5 & 11.0 & 39.0 \\
\hline $\begin{array}{l}\mathrm{C}: \\
\mathrm{n} / \mathrm{a}:\end{array}$ & \multicolumn{7}{|c|}{$\begin{array}{l}\text { Consumption Tax } \\
\text { non-applicable. For forced privatization, payroll tax is endogenous for payroll tax financing and zero for } \\
\text { income tax and consumption tax financing. }\end{array}$} \\
\hline $\begin{array}{ll}\text { PL: } & \operatorname{Pr} \\
\text { PL / 2: } & \operatorname{Pr} \\
\text { Y: } & \text { In }\end{array}$ & $\begin{array}{l}\text { nt Law payroll } \\
\text { nt Law payroll } \\
\text { ne Tax }\end{array}$ & $\begin{array}{l}\text { ax rate } \\
\text { ax rate divide }\end{array}$ & by 2 . & & & & \\
\hline
\end{tabular}


Table 4

Percentage Change in Labor Supply Relative to Steady State

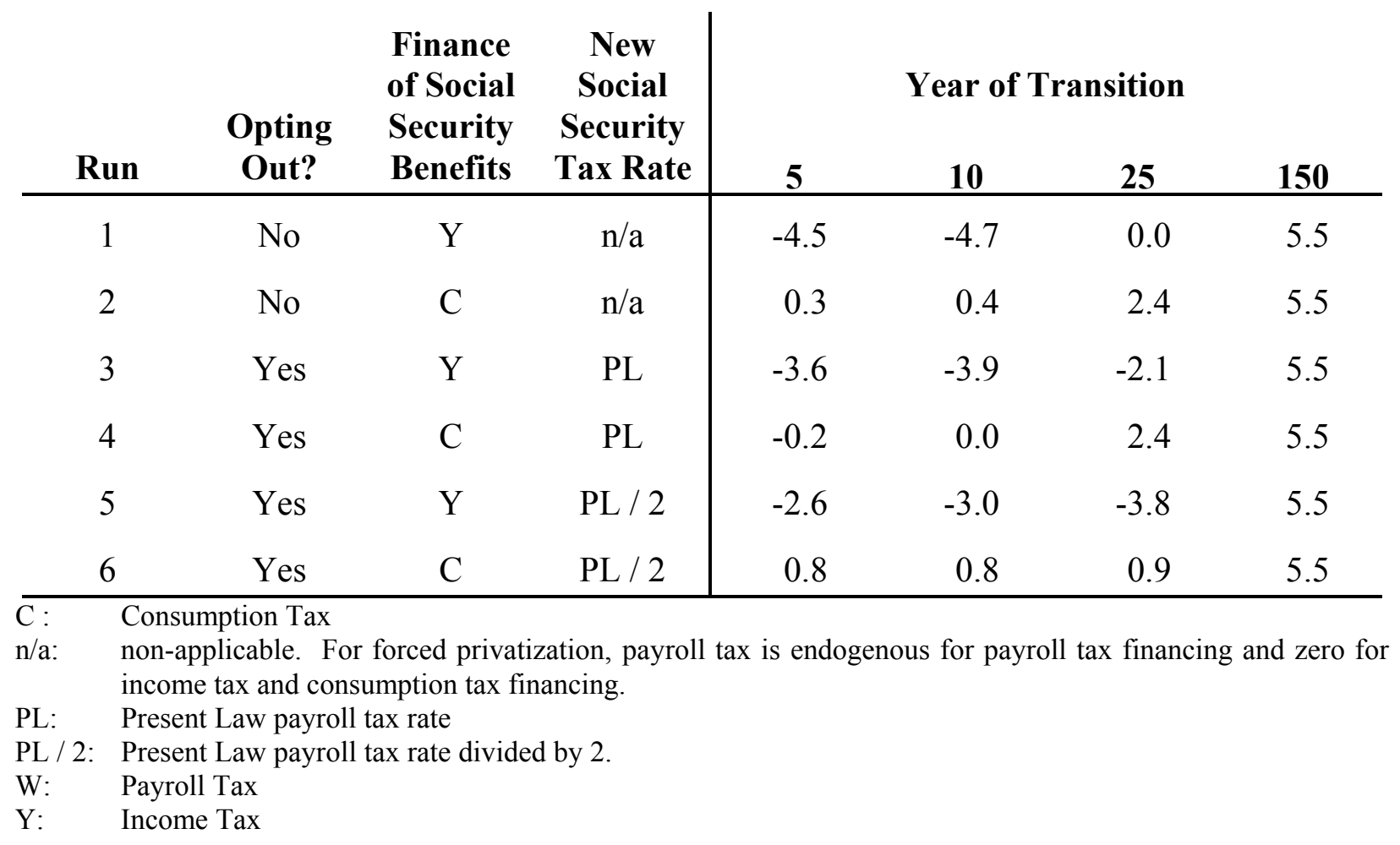


Table 5

\section{Percentage Change in Output Relative to Steady State}

\begin{tabular}{cccc|cccc} 
Run & $\begin{array}{c}\text { Opting } \\
\text { Out? }\end{array}$ & $\begin{array}{c}\text { Finance } \\
\text { of Social } \\
\text { Security } \\
\text { Benefits }\end{array}$ & $\begin{array}{c}\text { New } \\
\text { Social } \\
\text { Security } \\
\text { Tax Rate }\end{array}$ & \multicolumn{3}{|c}{ Year of Transition } & \\
\hline 1 & No & Y & n/a & -4.0 & -4.8 & -1.5 & 13.0 \\
2 & No & C & n/a & 0.6 & 1.3 & 4.9 & 13.0 \\
3 & Yes & Y & PL & -3.0 & -3.5 & -2.4 & 13.0 \\
4 & Yes & C & PL & 0.2 & 1.0 & 5.2 & 13.0 \\
5 & Yes & Y & PL / 2 & -2.3 & -3.0 & -4.0 & 13.0 \\
6 & Yes & C & PL / 2 & 1.0 & 1.5 & 3.3 & 13.0 \\
\hline
\end{tabular}

C: $\quad$ Consumption Tax

n/a: non-applicable. For forced privatization, payroll tax is endogenous for payroll tax financing and zero for income tax and consumption tax financing.

PL: $\quad$ Present Law payroll tax rate

PL / 2: Present Law payroll tax rate divided by 2 .

W: $\quad$ Payroll Tax 
Table 6

\section{Percentage Change in Wages Relative to Steady State}

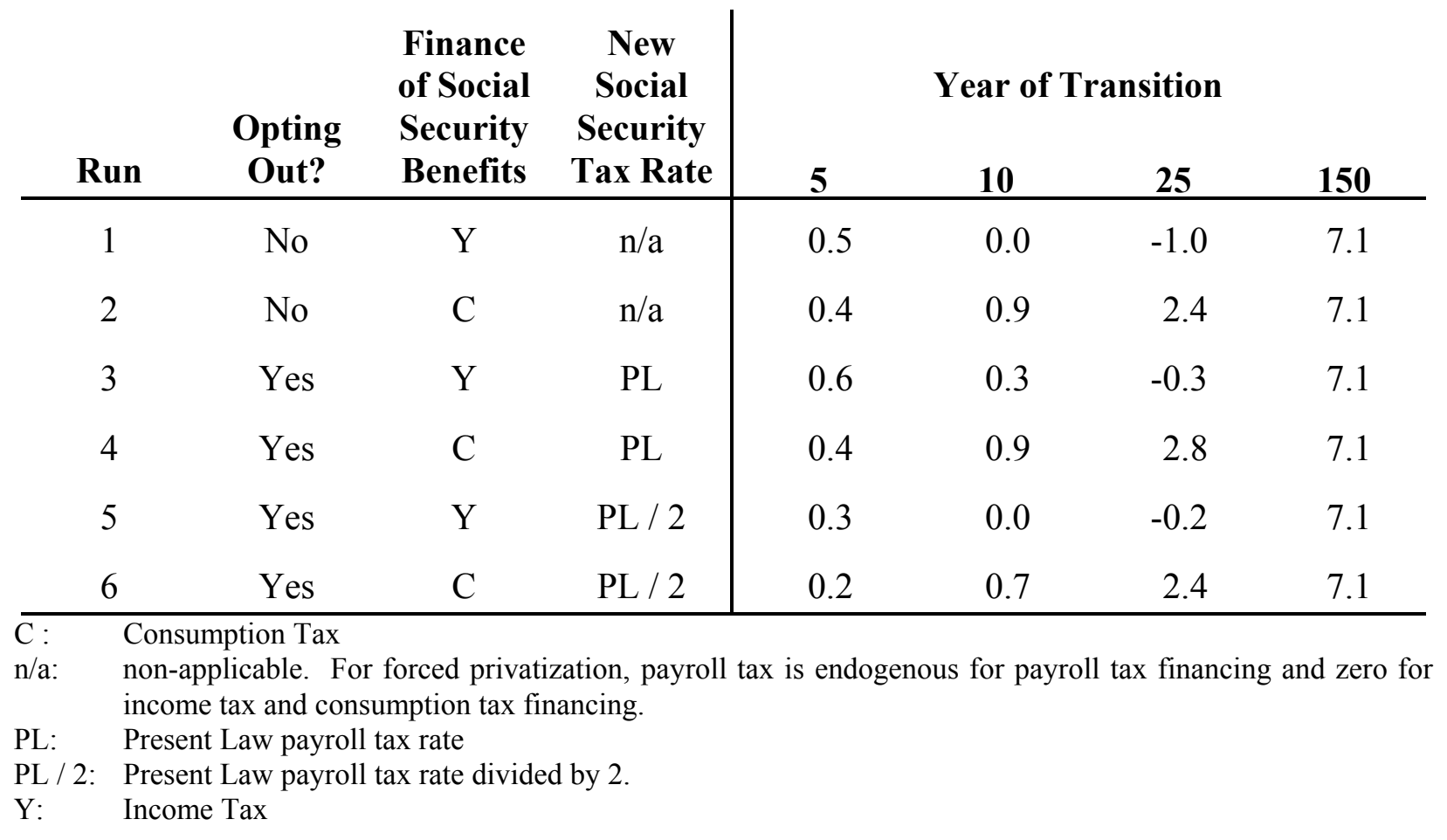


Table 7

Percentage Change in Interest Rates Relative to Steady State

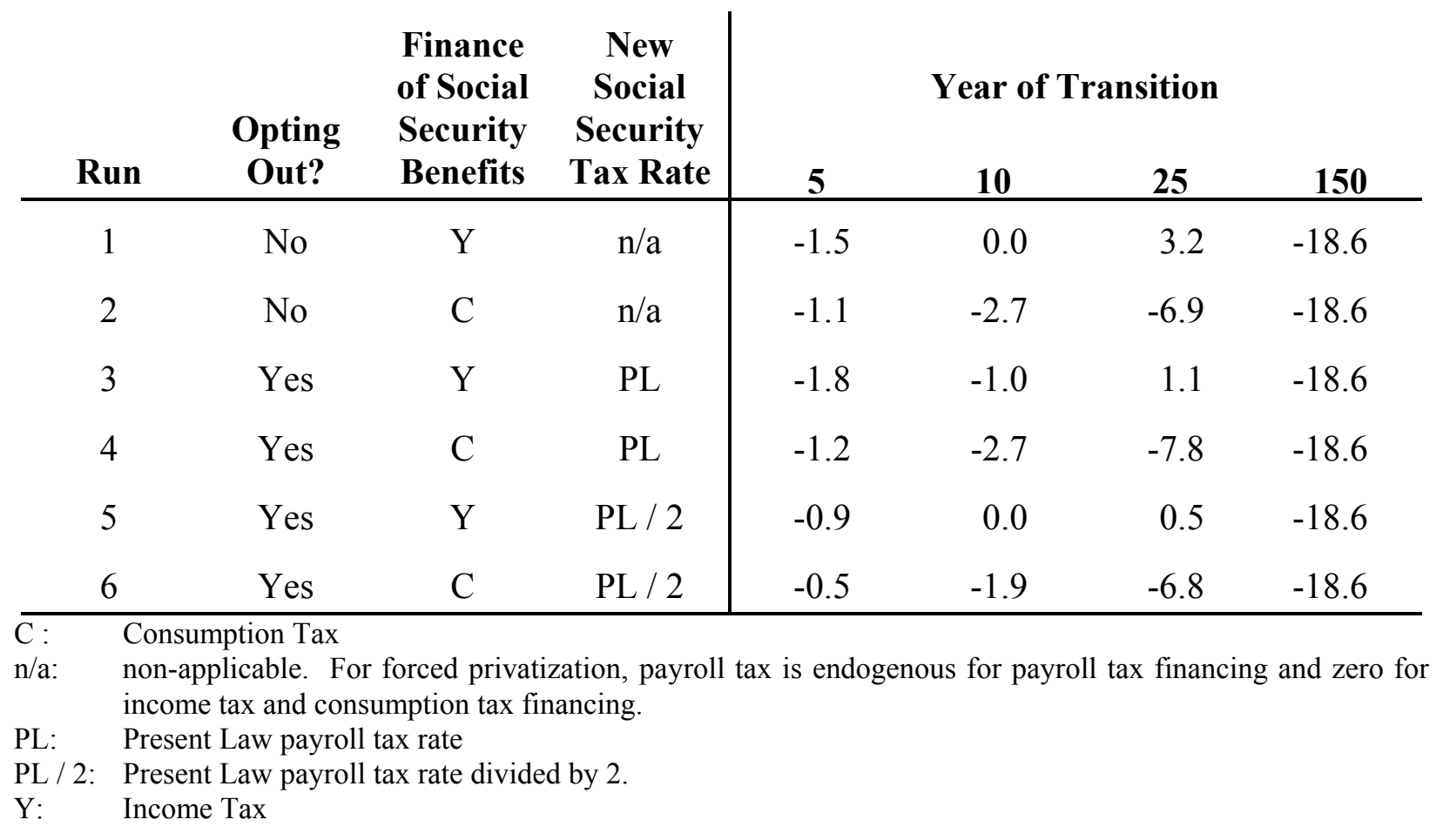


Table 8

Percentage Change in Remaining Lifetime Utility for Selected Income Classes

\begin{tabular}{|c|c|c|c|c|c|c|c|c|}
\hline \multicolumn{9}{|c|}{ Year of Birth } \\
\hline Run & Class & -54 & -25 & -10 & 1 & 10 & 25 & 150 \\
\hline \multirow[t]{5}{*}{1} & 1 & -0.1 & -0.2 & 1.6 & 3.2 & 3.1 & 3.5 & 6.0 \\
\hline & 3 & -1.4 & -1.6 & 0.0 & 1.4 & 1.7 & 3.3 & 7.4 \\
\hline & 6 & -1.3 & -2.1 & -0.7 & 0.7 & 1.1 & 3.2 & 8.0 \\
\hline & 9 & -1.2 & -2.4 & -1.0 & 0.3 & 0.8 & 3.1 & 8.1 \\
\hline & 12 & -1.7 & -3.6 & -3.6 & -3.0 & -2.5 & -0.2 & 4.4 \\
\hline \multirow[t]{5}{*}{2} & 1 & 0.7 & -2.1 & -0.6 & 0.5 & 1.3 & 3.2 & 6.0 \\
\hline & 3 & -0.4 & -2.0 & 0.0 & 1.2 & 2.1 & 4.2 & 7.4 \\
\hline & 6 & -0.9 & -1.7 & 0.3 & 1.6 & 2.6 & 4.8 & 8.0 \\
\hline & 9 & -1.2 & -1.6 & 0.5 & 1.7 & 2.7 & 4.9 & 8.1 \\
\hline & 12 & -1.5 & -2.5 & -1.8 & -1.0 & -0.1 & 1.7 & 4.4 \\
\hline \multirow[t]{5}{*}{3} & 1 & -0.1 & -0.5 & 0.7 & 3.2 & 3.4 & 3.8 & 6.0 \\
\hline & 3 & -0.9 & -2.1 & -0.2 & 1.8 & 2.2 & 4.2 & 7.4 \\
\hline & 6 & -0.9 & -2.9 & -0.5 & 1.3 & 1.7 & 4.3 & 8.0 \\
\hline & 9 & -0.9 & -3.3 & -0.7 & 1.0 & 1.4 & 4.2 & 8.1 \\
\hline & 12 & -1.1 & -3.8 & -3.0 & -2.2 & -1.9 & 0.9 & 4.4 \\
\hline \multirow[t]{5}{*}{4} & 1 & 0.5 & -2.2 & -1.0 & 0.9 & 1.6 & 4.2 & 6.0 \\
\hline & 3 & -0.3 & -2.7 & -0.2 & 1.6 & 2.4 & 5.2 & 7.4 \\
\hline & 6 & -0.6 & -2.8 & 0.3 & 2.0 & 2.9 & 5.8 & 8.0 \\
\hline & 9 & -0.8 & -2.8 & 0.5 & 2.2 & 3.1 & 5.9 & 8.1 \\
\hline & 12 & -1.0 & -2.9 & -1.6 & -0.6 & 0.1 & 2.5 & 4.4 \\
\hline
\end{tabular}


Table 8 Cont.

\begin{tabular}{ll|rrrrrrr} 
Run & Class & -54 & -25 & -10 & 1 & 10 & 25 & 150 \\
\hline 5 & 1 & -0.1 & 1.0 & 1.2 & 2.9 & 3.0 & 3.6 & 6.0 \\
& 3 & -0.9 & -0.7 & -0.4 & 1.5 & 1.5 & 2.9 & 7.4 \\
& 6 & -0.9 & -1.5 & -0.8 & 0.9 & 0.9 & 2.6 & 8.0 \\
& 9 & -0.9 & -1.9 & -1.0 & 0.6 & 0.6 & 2.4 & 8.1 \\
& 12 & -1.1 & -3.2 & -3.3 & -2.6 & -2.7 & -0.9 & 4.4 \\
\hline 6 & 1 & 0.5 & -0.8 & -0.8 & 0.5 & 1.0 & 2.8 & 6.0 \\
& 3 & -0.2 & -1.3 & -0.5 & 1.2 & 1.8 & 3.8 & 7.4 \\
& 6 & -0.6 & -1.4 & 0.1 & 1.7 & 2.2 & 4.3 & 8.0 \\
& 9 & -0.8 & -1.4 & 0.3 & 1.8 & 2.4 & 4.4 & 8.1 \\
& 12 & -1.0 & -2.3 & -1.7 & -0.9 & -0.4 & 1.3 & 4.4 \\
\hline
\end{tabular}

